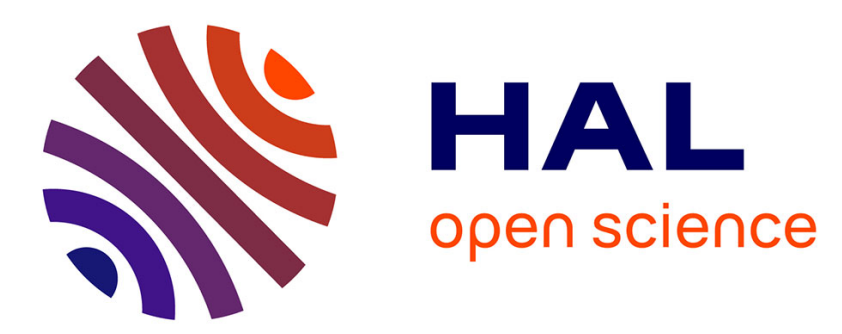

\title{
High-resolution mesoscale wind-resource assessment of Fiji using the Weather Research and Forecasting (WRF) model
}

Kunal Dayal, Gilles Bellon, John Cater, Michael Kingan, Rajnish Sharma

\section{- To cite this version:}

Kunal Dayal, Gilles Bellon, John Cater, Michael Kingan, Rajnish Sharma. High-resolution mesoscale wind-resource assessment of Fiji using the Weather Research and Forecasting (WRF) model. Energy, 2021, 232, pp.121047. 10.1016/j.energy.2021.121047 . hal-03365460

\author{
HAL Id: hal-03365460 \\ https://hal.science/hal-03365460
}

Submitted on 5 Oct 2021

HAL is a multi-disciplinary open access archive for the deposit and dissemination of scientific research documents, whether they are published or not. The documents may come from teaching and research institutions in France or abroad, or from public or private research centers.
L'archive ouverte pluridisciplinaire HAL, est destinée au dépôt et à la diffusion de documents scientifiques de niveau recherche, publiés ou non, émanant des établissements d'enseignement et de recherche français ou étrangers, des laboratoires publics ou privés. 
3 Kunal K. Dayal ${ }^{1 *}$, Gilles Bellon ${ }^{2}$, John E. Cater ${ }^{3}$, Michael J. Kingan ${ }^{1}$, and Rajnish N.

4 Sharma $^{1}$

$5{ }^{1}$ Department of Mechanical Engineering, University of Auckland, Auckland 1023, New Zealand.

6 Email: kday202@aucklanduni.ac.nz

$7 \quad{ }^{2}$ Department of Physics, University of Auckland, Auckland 1010, New Zealand.

$8{ }^{3}$ Department of Engineering Science, University of Auckland, Auckland 1010, New Zealand.

\section{Abstract}

11 This study presents a high-resolution mesoscale wind-resource assessment of the small island developing state (SIDS) of Fiji using a 10-year simulation of the Weather Research and Forecasting (WRF) model with convection-permitting resolution. Our analysis evaluates the wind speed and Weibull distributions, diurnal and seasonal wind speed patterns, resource maps of annual and seasonal wind speed, power density, model statistical analysis and interannual wind speed variability. The results reveal that the WRF-model simulated wind resource parameters are in good agreement with observations at 24 existing weather stations. At $55 \mathrm{~m}$ above ground, the annual mean wind speed and wind power density varies from 1.5 $\mathrm{m} / \mathrm{s}$ to $8 \mathrm{~m} / \mathrm{s}$ and $50 \mathrm{~W} / \mathrm{m}^{2}$ to $300 \mathrm{~W} / \mathrm{m}^{2}$, respectively, for onshore land areas. Higher wind speeds are observed during austral winter than in austral summer. Forty high wind-resource areas are identified in this study, which were previously unknown. This indicates that there is potential for utility-scale wind power generation at selected locations with wind speed and power density greater than $6.4 \mathrm{~m} / \mathrm{s}$ and $300 \mathrm{~W} / \mathrm{m}^{2}$ (NREL, Wind Power Class 3). An estimated $1000 \mathrm{MW}$ theoretical potential installed capacity is available for utility-scale wind power applications on Viti Levu and Vanua Levu.

\section{Key words:}

27 Wind energy, resource assessment, Wind power, WRF, Fiji

\section{Introduction}

29 Climate change and air pollution have propelled a steady growth of renewable electrical energy generation, and in particular wind energy on the global scale. Over the last decade, the global installed capacity of wind energy grew from 159 GW in 2009 to 651 GW in 2019 [1,

32 2]. This is an exponential growth with an estimated doubling time of approximately 4 years. 
33 Moreover, work is in progress in many countries with new resource assessments, wind farm construction permits and developments $[1,2]$.

Wind-resource assessment at different scales is fundamental for energy-resource modelling and site identification for the development of wind farms to support renewable electricity generation. Numerous methods are available for wind-resource assessment from microscale to mesoscale applications with each having its own benefits and disadvantages [3]. For microscale wind-resource assessment of a specific site or location within a domain of $10-20$ $\mathrm{km}$, microscale linear models like the Wind Atlas Analysis and Application Program (WAsP) are used. The model uses ground-based measured wind data for wind resource evaluation and resource mapping at a resolution of $50 \mathrm{~m} \times 50 \mathrm{~m}$ or less within the domain around a site [3]. For regional wind-resource assessment of a country or a group of islands, numerical models can be used to simulate the wind-resource for the region of study [3]. The most common numerical weather prediction (NWP) model used for atmospheric studies, which includes resource mapping, is the Weather Research and Forecasting (WRF) model [4]. The usefulness of the WRF model is its ability to simulate the atmospheric processes from the ground level to the stratosphere $20 \mathrm{~km}$ above. It provides an approximation of the surface atmospheric parameters like surface winds. It also has the advantage of generating mesoscale wind resource maps at different heights for resource identification, theoretical potential evaluation and for creating high-resolution wind data at $\mathrm{km}$ scale at locations whereby measurements are not available.

53 The WRF model has been used for wind energy resource mapping in Palestine [5], assessing 54 wind resource in Greece [6], modelling wind resource in complex terrain in Portugal [7], determining wind power characteristics of Oahu, Hawaii [8], assessing offshore wind resource off the Atlantic Iberian coast and in the Gulf of Thailand [9, 10] and for predicting wind energy resources in Tanzania [11]. In these studies, the model assisted in creating new knowledge about mesoscale wind resources and their characteristics, identified and classified the wind-resource sites and provided useful information for power generation purposes. To date, most downscaling studies for atmospheric parameters have been conducted in the midlatitude regions of the Northern Hemisphere and relatively few have examined semi-arid or tropical locations in the Southern Hemisphere.

63 Fiji is a small island developing state (SIDS), which is located between the latitudes of $12^{\circ} \mathrm{S}$ $64-22^{\circ} \mathrm{S}$ and longitudes of $177^{\circ} \mathrm{E}-178^{\circ} \mathrm{W}$ in the tropical Southwest Pacific region. There are 65332 islands in Fiji with a total land area of $18,333 \mathrm{~km}^{2}$, with 110 islands inhabited. Around 87 
66

$\%$ of the total land area is occupied by the two largest islands of Viti Levu and Vanua Levu, with areas of approximately $10,400 \mathrm{~km}^{2}$ and $5,540 \mathrm{~km}^{2}$, respectively. The islands of Fiji are mountainous and of volcanic origin, with maximum altitude of $1300 \mathrm{~m}$ above mean sea level. The overall climate in Fiji is categorized as a tropical marine climate with two seasons, which are classified as austral summer (wet season) extending from November to April and austral winter (dry season) from May to October.

In Fiji, electricity generation is from a mixture of renewable (hydro, biomass and wind) and conventional (industrial diesel and heavy fuel oil) power stations [12]. In the year 2019, 1060 GWh of electricity was generated with $58 \%(611 \mathrm{GWh})$ from renewable and $42 \%$ (450 GWh) from conventional power plants. The specific contribution from renewable energybased power plants include: $53 \%(559 \mathrm{GWh})$ from hydropower, $4.6 \%$ (49 $\mathrm{GWh})$ from biomass-based independent power producers and $0.25 \%(2.7 \mathrm{GWh})$ from wind [12]. Fiji aims to achieve $100 \%$ electricity generation from renewable energy sources by 2030 [13]. The extent to which wind electricity generation can contribute to this goal is unknown. Mapping wind resources on the mesoscale level will assist the SIDS of Fiji in terms of wind resource identification and quantification.

Several wind-resource assessment studies have been conducted in Fiji using the Wind Atlas Analysis and Application Program (WAsP) [14 - 21] and WindPRO [22]. These studies are confined to micro-scale locations covering small areas surrounding a measuring station in the range of 5-10 $\mathrm{km}^{2}$. Moreover, a recent study in Fiji using 5-6 years of measured automatic weather station wind data in WAsP identified three potential wind farm sites that can be further investigated for utility-scale wind power applications. The WAsP modelling revealed that each of these three sites could incorporate a minimum of 10 MW using Vergnet 275-kW wind turbines to support the electricity grid network [23]. To the knowledge of the authors, to date, no validated mesoscale wind-resource assessment has been carried out for the SIDS of Fiji.

Previous studies on the evaluation of the WRF model for simulating surface winds and the diurnal cycle of wind speed for the SIDS of Fiji showed that the standard $1.33 \mathrm{~km}$ by $1.33 \mathrm{~km}$ grid resolution in a $20 \mathrm{~km}-4 \mathrm{~km}-1.33 \mathrm{~km}$ grid nesting set up may not be an appropriate grid size to evaluate the surface winds for Fiji; as it was suspected that the topography was not properly resolved and a grid sensitivity study was recommended [24]. Following that recommendation, a grid sensitivity study of the WRF model for simulating the surface winds for the SIDS of Fiji was conducted and it was concluded that the $1 \mathrm{~km}$ by $1 \mathrm{~km}$ grid 
resolution of the $15 \mathrm{~km}-5 \mathrm{~km}-1 \mathrm{~km}$ grid configuration was appropriate to evaluate the wind resources for the SIDS of Fiji [25].

In this paper, we aim to answer two research questions:

I. Can the Weather Research and Forecasting (WRF) model be used to simulate the wind flow around the Fijian Islands in order to get sufficiently accurate information on the wind resources/potential?

II. Do the WRF simulations reveal sites that are promising for wind power that have not yet been identified?

107 This paper is an enhancement of the WRF mesoscale wind resource assessment approach applied to small tropical islands from an initial study [24] followed by a grid sensitivity study [25] to finally, the decade-long mesoscale wind resource assessment of Fiji. This study is also an application and evaluation of the mesoscale wind resource modelling using the WRF 111 model.

112 Therefore, we present the high-resolution mesoscale wind-resource assessment of the SIDS 113 of Fiji, which includes the analysis of the wind speed and the Weibull distributions, diurnal 114 and annual wind speed patterns, resource maps for wind speed and power density. The study 115 also presents the 10-year annual variability of wind speed and the model validation against 116 ground-based observations via a model statistical analysis. The purpose of this study is to test 117 a methodology to assess mesoscale wind-resource on tropical islands and to provide an 118 assessment of the wind-resource in Fiji. Section 2 of this work describes the methodology, 119 the results are presented in section 3, then discussed in section 4 and the conclusions are 120 presented in section 5 .

\section{2. Methodology}

\section{$122 \quad 2.1 \quad$ Study area and wind measuring stations}

123 Figure 1 shows the model topographical height contours at a resolution of 30-arc-seconds for 124 the study area, which covers the larger islands and the smaller islands in the surrounding 125 waters and is marked with the locations of 24 automatic weather stations (AWSs) of Fiji 126 Meteorological Services. Time series and uninterrupted measured wind data is available for 3 127 years $(2016-2018)$ from the 24 AWSs at an elevation of $10 \mathrm{~m}$ above ground level. This data 128 is used for the model validation exercise for the surface winds. 
129 The individual station locations are shown in Figure 1, where fourteen stations are located on 130 Viti Levu, five on Vanua Levu and five on the outer islands. Eleven stations are located on 131 the leeward side of the two larger islands: Keiyasi, Labasa, Momi, Nadarivatu, Nadi, 132 Rakiraki, Rarawai, Seaqaqa, Sigatoka, Wainikoro and Yaqara stations. Eight stations are 133 located on the windward side of the two larger islands: Korolevu, Lomaivuna, Nausori, RKS 134 Lovoni, Saqani, Suva, Tokotoko and Udu stations. The five stations located on the outer 135 islands are Koro Island, Levuka, Viwa, Vunisea and Yasawa stations.

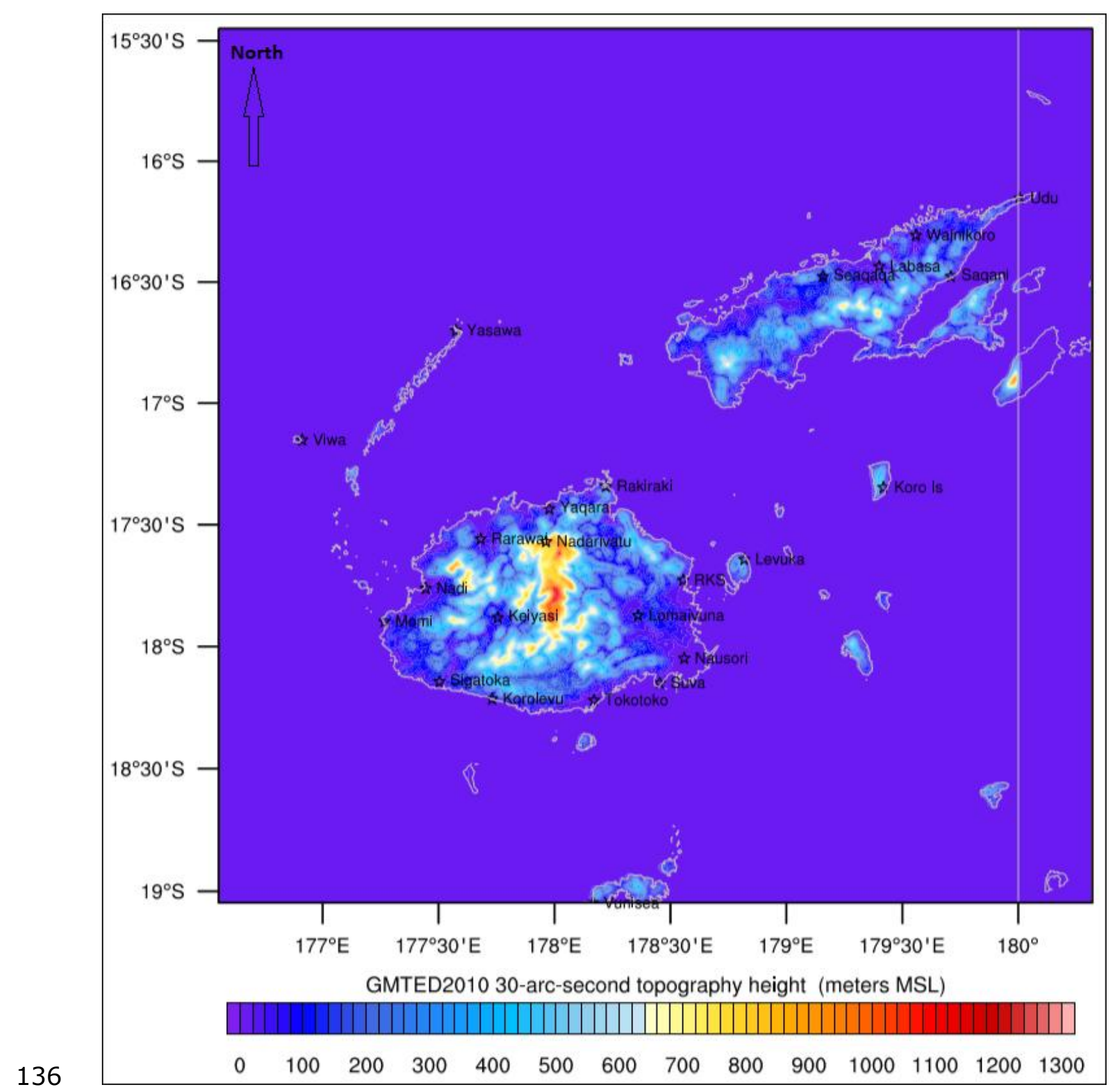

137 Figure 1. Topographical map of the study area (Fiji) with the locations of the AWSs. 
138 A summary of the characteristics of the AWSs from which the wind observations are 139 retrieved is shown in Table 1. The elevation of the AWSs is given in metres above sea level 140 (m a.s.1.). The model terrain elevation of each AWS is the $1 \mathrm{~km} \times 1 \mathrm{~km}$ grid cell average 141 taken from the grid cell in which the AWS is located. Table 1. Details and position of AWSs.

\begin{tabular}{lccrr}
\hline Station Name & $\begin{array}{c}\text { Latitude } \\
\left({ }^{\circ} \mathrm{S}\right)\end{array}$ & $\begin{array}{c}\text { Longitude } \\
\left({ }^{\circ} \mathrm{E}\right)\end{array}$ & $\begin{array}{c}\text { Elevation } \\
(\mathrm{m} \text { a.s.1. })\end{array}$ & $\begin{array}{c}\text { WRF } \\
\text { Elevation }(\mathrm{m} \text { a.s.1.) }\end{array}$ \\
\hline Keiyasi & -17.8795 & 177.7552 & 89.8 & 63.7 \\
Koro Island & -17.3450 & 179.4184 & 108.8 & 80.1 \\
Korolevu & -18.2129 & 177.7304 & 25.7 & 41.5 \\
Labasa & -16.4333 & 179.4000 & 8.5 & 13.1 \\
Levuka & -17.6403 & 178.8186 & 41.5 & 43.1 \\
Lomaivuna & -17.8714 & 178.3601 & 122.1 & 128.5 \\
Momi & -17.8952 & 177.2668 & 43.8 & 25.9 \\
Nadarivatu & -17.5676 & 177.9632 & 824.1 & 761.8 \\
Nadi & -17.7599 & 177.4448 & 20.7 & 14.9 \\
Nausori & -18.0464 & 178.5591 & 5.7 & 4.9 \\
Rakiraki & -17.3404 & 178.2214 & 8.1 & 3.4 \\
Rarawai & -17.5564 & 177.6814 & 9.3 & 17.0 \\
RKS Lovoni & -17.7260 & 178.5551 & 17.1 & 14.1 \\
Saqani & -16.4749 & 179.7089 & 30.0 & 109.2 \\
Seaqaqa & -16.4758 & 179.1578 & 101.8 & 12.0 \\
Sigatoka & -18.1422 & 177.5039 & 6.7 & 15.6 \\
Suva & -18.1475 & 178.4536 & 6.6 & 6.2 \\
Tokotoko & -18.2186 & 178.1700 & 4.9 & 0.3 \\
Udu & -16.1411 & -179.9947 & 43.7 & 1.0 \\
Viwa & -17.1494 & 176.9117 & 2.0 & 86.3 \\
Vunisea & -19.0469 & 178.1654 & 31.9 & 15.3 \\
Wainikoro & -16.3044 & 179.5586 & 15.1 & 5.1 \\
Yaqara & -17.4330 & 177.9774 & 20.0 & \\
Yasawa & -16.6984 & 177.5746 & 40.0 & \\
\hline & & & &
\end{tabular}

\section{$144 \quad 2.2 \quad$ Model and simulation set-up}

145 The study uses the Weather Research and Forecasting (WRF) model version 3.9.1.1 of the 146 Advanced Research (ARW) solver, a widely used community mesoscale model developed by 147 the National Centre for Atmospheric Research (NCAR) [26, 27]. The dynamical downscaling 148 method was used for running simulations, whereby coarse resolution output from an analysis 149 using a General Circulation Model (GCM) are used as initial and boundary conditions to 150 drive a regional numerical model to simulate atmospheric parameters via nesting, considering 151 the local conditions [28 - 30].

152 The initial and boundary conditions for the SIDS of Fiji were obtained from 6-hourly NCEP153 FNL (Final) Operational Global Analysis data at $1^{\circ} \times 1^{\circ}$ grid resolution [31]. The static 
154 fields for the topography were obtained from the USGS GMTED2010 dataset. The land155 water masks, land use/land cover classification, albedo etc. were obtained and interpolated 156 from the 21-class MODIS and MODIS FPAR. These were taken from the National Center for 157 Atmospheric Research (NCAR) database, at a resolution of 30-arc-seconds [32]. Time 158 varying sea surface temperatures (SSTs) were supplied to the model from NCEP-NOAA at a 159 grid resolution $0.083^{\circ} \times 0.083^{\circ}[33]$.

160 The input data from NCEP-FNL were downscaled by the WRF model using three nested 161 domains as illustrated in Figure 2. The outermost domain is referred to as d01, the second d02 162 and the innermost as d03 (which is also the domain shown in Figure 1).

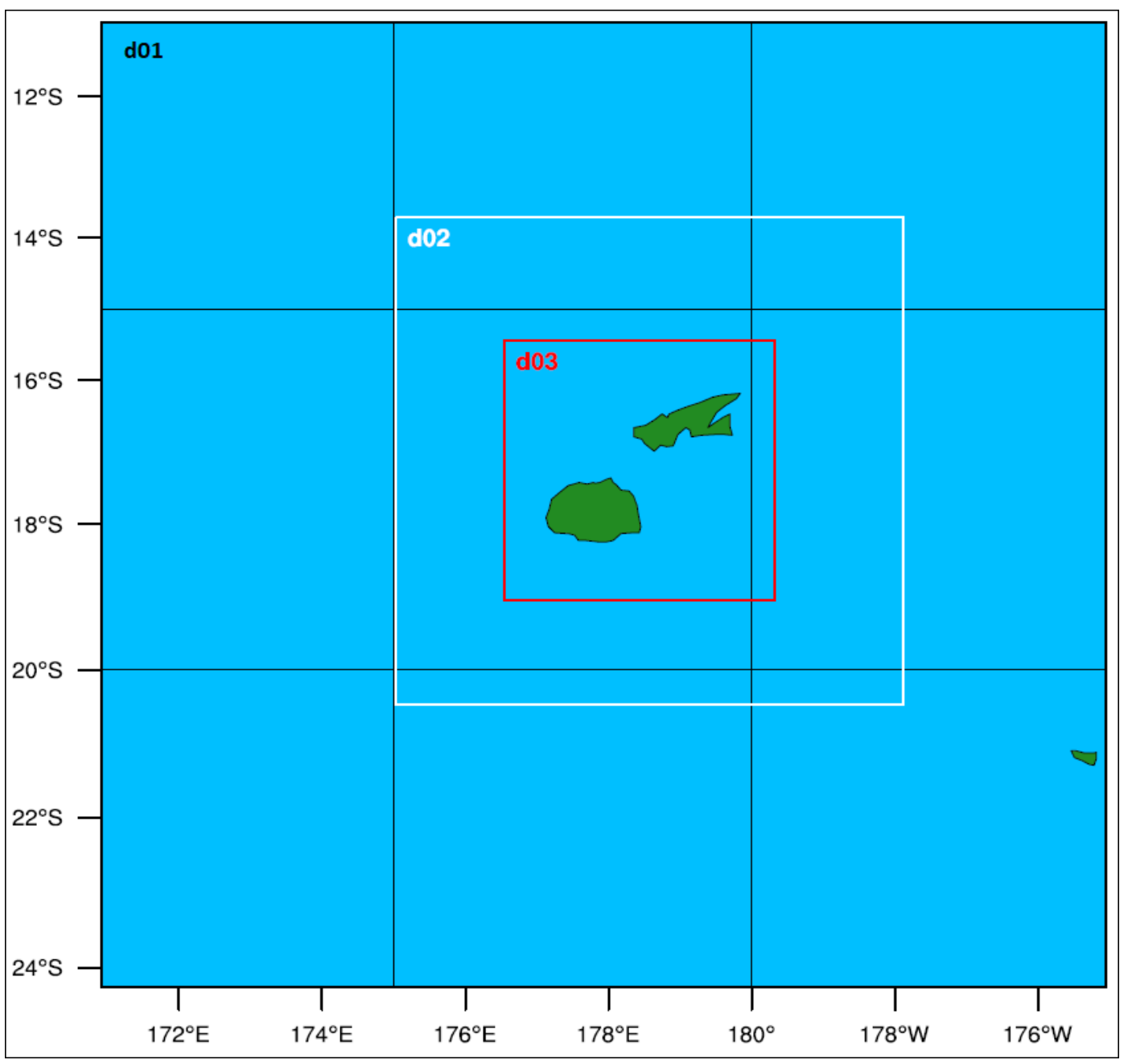

Figure 2. Simulation domains.

165 The two-way nesting approach was applied for the parent-child grid interaction, where the 166 flow of information goes from the coarser domain to the finer domain, with feedback from 167 the inner domains. All domains are centred at a latitude of $17.73^{\circ} \mathrm{S}$ and longitude of 
$168177.94^{\circ} \mathrm{E}$, which corresponds to the centre of Viti Levu using the Mercator projection as 169 recommended for low latitudes [26, 27].

170 The spatial coverage of each of the three domains are: $\mathrm{d} 01=1500 \mathrm{~km} \times 1500 \mathrm{~km}(100 \times$ 171100 grid cells $), \quad \mathrm{d} 02=755 \mathrm{~km} \times 755 \mathrm{~km}(151 \times 151$ grid cells $)$ and $\mathrm{d} 03=401 \mathrm{~km} \times$ $172401 \mathrm{~km}(401 \times 401$ grid cells $)$ at a horizontal resolution of $15 \mathrm{~km} \times 15 \mathrm{~km}, 5 \mathrm{~km} \times 5 \mathrm{~km}$ 173 and $1 \mathrm{~km} \times 1 \mathrm{~km}$, respectively. The vertical spacing of the three domains consist of 30 174 terrain-following vertical coordinates, including eight levels below $1 \mathrm{~km}$, as meteorological 175 parameters of interest are in the lower part of the atmosphere, close to the surface. A timestep 176 of 10 seconds is used in d03 following a 3:1 parent-child grid timestep ratio to ensure 177 numerical stability as recommended in refs. [26 and 27]. The choice of $15 \mathrm{~km}-5 \mathrm{~km}-$ $1781 \mathrm{~km}$ nested grids follows the recommendation of the earlier grid sensitivity study [24], in 179 keeping with the standard practice of using a 3:1 or 5:1 parent-grid ratio $[26,27]$.

180 The well-tested tropical suite of the WRF physics parameterization scheme was used for the 181 model physics options [26, 27]. The parameterization of deep convection was only used on 182 the larger domains ( $\mathrm{d} 01$ and $\mathrm{d} 02$ ), as the vertical fluxes due to convection updrafts and 183 downdrafts and the compensating motion outside the clouds cannot be resolved explicitly at 184 grid scales of $5 \mathrm{~km}$ and above [26, 27]. The remaining physics options are the same for all 185 three domains as shown in Table 2.

Table 2. Physics Parameterization

\begin{tabular}{ll}
\hline Parameterization Options & \\
\hline Long-wave radiation & RRTMG \\
Short-wave radiation & RRTMG \\
Microphysics & WRF Single-Moment 6-class \\
Surface Layer & MM5 Similarity \\
Planetary Boundary Layer & Yonsei University \\
Cumulus & New Tiedtke \\
Land Surface Model & Noah \\
\hline
\end{tabular}

188 Simulations for the 10 years were performed in monthly segments on the New Zealand 189 eScience Infrastructure (NeSI) High Performance Computer - Mahuika. The model was 190 initiated from 3 days prior to the start of each month and these 3 days are the model spin-up 191 time and are excluded from the analysis. The model is set to restart every 2 days to avoid 192 model drift as recommended for longer simulations [26, 27]. Even though a period of one 193 year has been considered adequate to capture the diurnal and seasonal variations for wind resource assessment [34], in our case, we use 10 years of simulations to provide a better 
195 representation of the diurnal and seasonal variations. The simulation results discussed in the 196 paper are 1-hourly 10-metre-elevation wind speeds retrieved from the simulation on the 197 innermost domain (d03) considering the grid cell containing the AWS as representative of the 198 station.

\section{$199 \quad 2.3 \quad$ Model Validation}

200 The validation of a numerical weather prediction (NWP) model can be done according to 201 various methodologies that complement each other [35]. Five statistical parameters are used 202 for the model evaluation. The Root Mean Square Error (RMSE) is defined as:

$$
\operatorname{RMSE}=\left[\frac{1}{N} \sum_{i=1}^{N}\left(M_{i}-O_{i}\right)^{2}\right]^{\frac{1}{2}},
$$

203 in which $M_{i}$ is the simulated variable at the $i^{\text {th }}$ data point, $O_{i}$ is the corresponding observed 204 variable and $N$ is the total number of simulation-observation pairs of values.

205 The mean Bias was used for the evaluation of data tendency. A positive (negative) bias 206 means the simulations overestimate (underestimate) the measured values:

$$
\operatorname{Bias}=\frac{1}{N} \sum_{i=1}^{N}\left(M_{i}-O_{i}\right)
$$

207 The Standard Deviation Error (STDE) was used to evaluate the dispersion of the error 208 between the observed and the simulated data:

$$
\operatorname{STDE}=\left[\frac{1}{N} \sum_{i=1}^{N}\left(M_{i}-O_{i}\right)^{2}-B_{i a s^{2}}\right]^{\frac{1}{2}} .
$$

209 The RMSE, Bias and STDE was used to evaluate the hourly-simulated wind speed against 210 the observed wind speed.

211 Most emphasis is given to STDE, and this assumption comes from the fact that, even if a 212 simulation has a high RMSE or Bias, if the STDE is low it means that the error is somewhat 213 constant and can be seen as an offset and the simulation physics is correct. If the simulation 214 has a high STDE, the error is more scattered and the simulations have low physical meaning $215[36,37]$.

216 The surface wind speed distribution is well approximated by a Weibull distribution [38, 39] 217 and this distribution is therefore used to evaluate the model-simulated wind distributions 218 against observed wind distributions. The Weibull distribution is a two-parameter function, 
219 mathematically represented by a probability density function (PDF), $f(u)$ while the 220 cumulative distribution function is represented by $F(u)$. These functions are defined as:

$$
f(u)=\frac{k}{A}\left(\frac{u}{A}\right)^{k-1} e^{-\left(\frac{u}{A}\right)^{k}}
$$

221 and

$$
F(u)=1-e^{-\left(\frac{u}{A}\right)^{k}},
$$

222 where $u$ is the reference wind speed at the height of measurement, $k$ the non-dimensional 223 shape parameter, and $A$ the scale parameter whose dimension coincides with that of $u(\mathrm{~m} / \mathrm{s})$.

224 Note that $k, A, u>0$. The scale parameter, $A$, indicates on average how windy the site is, 225 whilst the shape parameter, $k$, indicates how 'peaked' the distribution is. The model and the 226 measured Weibull $A$ and $k$ parameters are used for comparison.

227 The Pearson correlation coefficient was used to evaluate the diurnal cycle of wind speed and 228 the Weibull probability density functions. The Pearson correlation coefficient is a statistical 229 measure that quantifies the strength of the relationship between the relative variation of two 230 variables; in our case, the simulated and the measured yearly averaged diurnal values and the 231 Weibull parameter values.

\section{$232 \quad 2.4 \quad$ Resource maps}

233 The 10-year $1 \mathrm{~km} \times 1 \mathrm{~km}$ model simulation results from domain 3 (d03) were used to 234 generate the annual mean wind speed, seasonal mean wind speed and wind power density 235 resource maps at $55 \mathrm{~m}$ elevation, which is equivalent to the typical wind turbine hub height. 236 This was done to assist in identifying potential wind resource sites for utility-scale wind 237 power applications.

\section{$238 \quad 2.5 \quad$ Interannual wind speed variability}

239 Interannual wind speed anomalies were calculated by subtracting the measured long-term 240 mean wind speed from the model annual mean wind speed for individual stations for 10241 years. These were plotted to study the variation of the wind speeds from year to year.

$242 \quad 3 . \quad$ Results

243 This section presents the results in two parts: the model validation and the resource maps.

\section{$244 \quad 3.1 \quad$ Model Validation}

245 The 10-metre-elevation results for the parameters used to validate the model against ground246 based measurements, include: the model statistical analysis, wind speed distribution and 
247 Weibull PDFs, and the diurnal and annual wind speed patterns. The model results are 248 compared with locations where the measurements are available from AWSs.

\section{$249 \quad$ 3.1.1 Model Statistical Analysis}

250 Tables 3 - 5 present the model statistical analysis for 3 years for the leeward side, windward 251 side and the outer islands AWSs, respectively. These also present the 3-year averaged wind 252 speed diurnal cycle correlation between the model and the measurements for individual 253 station locations. The mean bias for 3 years across all 24 AWSs is $0.62 \mathrm{~m} / \mathrm{s}$, which is a 20.2 $254 \%$ overestimate in comparison with the measured wind speed. The mean RMSE is $2.22 \mathrm{~m} / \mathrm{s}$, 255 the mean STDE is $2.00 \mathrm{~m} / \mathrm{s}$ and the mean diurnal cycle correlation is 0.81 for the locations 256 tested.

Table 3. Wind statistics from the leeward side AWSs (2016 - 2018)

\begin{tabular}{lccccccc}
\hline Station & $\begin{array}{c}\text { Measured } \\
\text { Mean }(\mathrm{m} / \mathrm{s})\end{array}$ & $\begin{array}{c}\text { WRF } \\
\text { Mean }(\mathrm{m} / \mathrm{s})\end{array}$ & $\begin{array}{c}\text { Bias } \\
(\mathrm{m} / \mathrm{s})\end{array}$ & Bias \% & $\begin{array}{c}\text { RMSE } \\
(\mathrm{m} / \mathrm{s})\end{array}$ & $\begin{array}{c}\text { STDE } \\
(\mathrm{m} / \mathrm{s})\end{array}$ & $\begin{array}{c}\text { Correlation } \\
(\%)\end{array}$ \\
\hline Keiyasi & 1.15 & 1.86 & 0.71 & 61.9 & 1.51 & 1.34 & 0.99 \\
Labasa & 1.57 & 2.94 & 1.37 & 87.3 & 1.99 & 1.44 & 0.91 \\
Momi & 4.14 & 3.20 & -0.94 & -22.6 & 2.23 & 2.03 & 0.70 \\
Nadarivatu & 2.81 & 3.54 & 0.73 & 25.9 & 2.00 & 1.87 & 0.58 \\
Nadi & 2.77 & 2.79 & 0.02 & 0.7 & 1.68 & 1.68 & 0.89 \\
Rakiraki & 6.10 & 5.53 & -0.57 & -9.4 & 2.30 & 2.23 & 0.95 \\
Rarawai & 1.77 & 1.61 & -0.17 & -9.4 & 1.38 & 1.37 & 0.99 \\
Seaqaqa & 1.36 & 2.20 & 0.83 & 61.2 & 1.78 & 1.57 & 0.97 \\
Sigatoka & 1.89 & 2.41 & 0.53 & 27.8 & 1.38 & 1.28 & 0.98 \\
Wainikoro & 1.65 & 3.49 & 1.84 & 111.1 & 2.61 & 1.85 & 0.94 \\
Yaqara & 3.98 & 3.93 & -0.05 & -1.3 & 1.73 & 1.73 & 0.86 \\
\hline Average & 2.65 & 3.05 & 0.39 & 30.3 & 1.87 & 1.67 & 0.89 \\
\hline
\end{tabular}

258

259

Table 4. Wind statistics from the windward side AWSs (2016 - 2018)

\begin{tabular}{lccccccc}
\hline Station & $\begin{array}{c}\text { Measured } \\
\text { Mean }(\mathrm{m} / \mathrm{s})\end{array}$ & $\begin{array}{c}\text { WRF } \\
\text { Mean }(\mathrm{m} / \mathrm{s})\end{array}$ & $\begin{array}{c}\text { Bias } \\
(\mathrm{m} / \mathrm{s})\end{array}$ & $\begin{array}{c}\text { Bias } \\
\%\end{array}$ & $\begin{array}{c}\text { RMSE } \\
(\mathrm{m} / \mathrm{s})\end{array}$ & $\begin{array}{c}\text { STDE } \\
(\mathrm{m} / \mathrm{s})\end{array}$ & $\begin{array}{c}\text { Correlation } \\
(\%)\end{array}$ \\
\hline Korolevu & 3.30 & 3.88 & 0.58 & 17.5 & 1.85 & 1.76 & 0.94 \\
Lomaivuna & 1.98 & 2.61 & 0.63 & 31.8 & 1.65 & 1.52 & 0.97 \\
Nausori & 1.94 & 3.08 & 1.14 & 58.9 & 2.59 & 2.32 & 0.90 \\
RKS Lovoni & 2.06 & 3.95 & 1.89 & 91.8 & 2.67 & 1.89 & 0.10 \\
Saqani & 2.80 & 4.17 & 1.36 & 48.7 & 4.15 & 3.92 & 0.47 \\
Suva & 2.36 & 3.24 & 0.88 & 37.4 & 2.22 & 2.04 & 0.93 \\
Tokotoko & 2.57 & 3.18 & 0.61 & 23.6 & 2.18 & 2.09 & 0.95 \\
Udu & 5.36 & 4.80 & -0.56 & -10.5 & 1.96 & 1.88 & 0.72 \\
\hline Average & 2.80 & 3.61 & 0.82 & 37.4 & 2.41 & 2.18 & 0.75 \\
\hline
\end{tabular}

Table 5. Wind statistics from the outer islands' AWSs $(2016$ - 2018)

\begin{tabular}{lccccccc}
\hline Station & $\begin{array}{c}\text { Measured } \\
\text { Mean }(\mathrm{m} / \mathrm{s})\end{array}$ & $\begin{array}{c}\text { WRF } \\
\text { Mean }(\mathrm{m} / \mathrm{s})\end{array}$ & $\begin{array}{c}\text { Bias } \\
(\mathrm{m} / \mathrm{s})\end{array}$ & Bias $\%$ & $\begin{array}{c}\text { RMSE } \\
(\mathrm{m} / \mathrm{s})\end{array}$ & $\begin{array}{c}\text { STDE } \\
(\mathrm{m} / \mathrm{s})\end{array}$ & $\begin{array}{c}\text { Correlation } \\
(\%)\end{array}$ \\
\hline Koro Island & 3.94 & 4.47 & 0.53 & 13.4 & 2.00 & 1.93 & 0.69 \\
Levuka & 3.82 & 5.15 & 1.33 & 34.7 & 2.79 & 2.46 & 0.85
\end{tabular}




\begin{tabular}{llllllll} 
Viwa & 3.84 & 5.92 & 2.08 & 54.0 & 3.47 & 2.78 & 0.92 \\
Vunisea & 4.02 & 4.58 & 0.56 & 13.9 & 2.60 & 2.54 & 0.52 \\
Yasawa & 6.27 & 5.87 & -0.39 & -6.3 & 2.49 & 2.45 & 0.68 \\
\hline Average & 4.38 & 5.20 & 0.82 & 21.9 & 2.67 & 2.43 & 0.73 \\
\hline
\end{tabular}

263 Since the mean STDE for all AWSs is low, which is below the border threshold of \pm 2.50

$264 \mathrm{~m} / \mathrm{s}$, this indicates that the model adequately captures the physical processes [35, 36 and 37].

265 The 10-metre-elevation model errors reported are assumed to be the equivalent at higher 266 elevations of interest, for instance at the hub-height of $55 \mathrm{~m}$.

\section{3.1.2 Wind Speed Distribution and Weibull PDFs}

268 The wind speed distribution provides site-specific information in terms of the Weibull $A$ 269 and $k$ parameters. Tables $6-8$ present the wind speed distribution parameter analysis for 3 270 years for the leeward side, windward side and the outer islands, respectively. Higher Weibull $271 A(>4 \mathrm{~m} / \mathrm{s})$ and $k(>2)$ parameters are observed and modelled at Momi, Rakiraki, Yaqara, 272 Udu, Koro Island, Levuka, Vunisea, Viwa and Yasawa. These sites are considered windy and 273 have little variation from the mean wind speed, which indicates the presence of consistent, 274 regular wind resources.

Table 6. Weibull Wind Distribution parameters for leeward side AWSs (2016 - 2018)

\begin{tabular}{|c|c|c|c|c|c|c|c|c|c|}
\hline Station & $\begin{array}{c}\text { Measure } \\
\mathrm{d} \\
\text { Weibull } \\
A(\mathrm{~m} / \mathrm{s})\end{array}$ & $\begin{array}{c}\text { WRF } \\
\text { Weibul } \\
1 \\
A(\mathrm{~m} / \mathrm{s})\end{array}$ & $\begin{array}{l}\text { Weibul } \\
1 A \text { Bias }\end{array}$ & Bias \% & $\begin{array}{c}\text { Measure } \\
\text { d } \\
\text { Weibull } \\
k\end{array}$ & $\begin{array}{c}\text { WRF } \\
\text { Weibul } \\
1 \\
k\end{array}$ & $\begin{array}{l}\text { Weibul } \\
1 k \text { Bias }\end{array}$ & $\begin{array}{c}\text { Bias } \\
\%\end{array}$ & $\begin{array}{c}\text { Weibull } \\
\text { Correlatio } \\
\mathrm{n}\end{array}$ \\
\hline Keiyasi & 1.17 & 2.02 & 0.85 & 72.5 & 1.17 & 1.21 & 0.05 & 4.0 & 0.95 \\
\hline Labasa & 1.70 & 3.35 & 1.65 & 97.5 & 1.35 & 2.69 & 1.34 & 99.5 & 0.60 \\
\hline $\begin{array}{l}\text { Momi } \\
\text { Nadarivat }\end{array}$ & 4.56 & 3.63 & -0.93 & -20.3 & 1.99 & 2.31 & 0.31 & 15.8 & 0.95 \\
\hline $\mathrm{u}$ & 3.15 & 4.07 & 0.92 & 29.5 & 1.71 & 2.17 & 0.46 & 26.6 & 0.90 \\
\hline Nadi & 3.03 & 3.17 & 0.14 & 6.0 & 1.65 & 2.33 & 0.68 & 41.3 & 0.95 \\
\hline Rakiraki & 7.11 & 6.21 & -0.90 & -12.6 & 2.44 & 2.42 & -0.02 & -0.7 & 0.97 \\
\hline Rarawai & 1.91 & 1.79 & -0.12 & -6.3 & 1.40 & 1.42 & 0.02 & 1.8 & 1.00 \\
\hline Seaqaqa & 1.48 & 2.44 & 0.96 & 64.8 & 1.23 & 1.42 & 0.19 & 15.8 & 0.94 \\
\hline Sigatoka & 2.11 & 2.69 & 0.58 & 27.6 & 1.58 & 1.47 & -0.11 & -7.1 & 0.98 \\
\hline Wainikoro & 1.88 & 3.99 & 2.11 & 112.6 & 1.40 & 2.28 & 0.89 & 63.7 & 0.59 \\
\hline Yaqara & 4.47 & 4.32 & -0.15 & -3.2 & 2.24 & 1.96 & -0.28 & -12.7 & 0.99 \\
\hline Average & 2.96 & 3.43 & 0.46 & 33.5 & 1.65 & 1.97 & 0.32 & 22.55 & 0.89 \\
\hline
\end{tabular}

Table 7. Weibull Wind Distribution parameters for windward side AWSs (2016 - 2018)

\begin{tabular}{|c|c|c|c|c|c|c|c|c|c|}
\hline Station & $\begin{array}{c}\text { Measure } \\
\mathrm{d} \\
\text { Weibull } \\
A(\mathrm{~m} / \mathrm{s})\end{array}$ & $\begin{array}{c}\text { WRF } \\
\text { Weibul } \\
1 \\
A(\mathrm{~m} / \mathrm{s})\end{array}$ & $\begin{array}{l}\text { Weibul } \\
1 A \text { Bias }\end{array}$ & $\begin{array}{c}\text { Bias } \\
\%\end{array}$ & $\begin{array}{c}\text { Measure } \\
\mathrm{d} \\
\text { Weibull } \\
k\end{array}$ & $\begin{array}{c}\text { WRF } \\
\text { Weibul } \\
1 \\
k\end{array}$ & $\begin{array}{r}\text { Weibul } \\
1 k \text { Bias }\end{array}$ & Bias \% & $\begin{array}{c}\text { Weibull } \\
\text { Correlatio } \\
\mathrm{n}\end{array}$ \\
\hline Korolevu & 3.65 & 4.31 & 0.67 & 18.3 & 1.94 & 2.14 & 0.20 & 10.3 & 0.96 \\
\hline
\end{tabular}




\begin{tabular}{llllllllll} 
Lomaivun & & & & & & & & \\
a & 2.15 & 2.91 & 0.76 & 35.4 & 1.54 & 1.73 & 0.18 & 11.8 & 0.95 \\
Nausori & 2.71 & 3.45 & 0.75 & 28.0 & 1.51 & 1.82 & 0.31 & 20.4 & 0.94 \\
RKS & 2.32 & 4.36 & 2.05 & 89.3 & 1.64 & 2.39 & 0.75 & 45.4 & 0.62 \\
Saqani & 2.40 & 4.66 & 2.26 & 95.5 & 1.27 & 2.65 & 1.39 & 120.8 & 0.52 \\
Suva & 2.58 & 3.68 & 1.10 & 42.7 & 1.76 & 1.80 & 0.04 & 2.2 & 0.92 \\
Tokotoko & 2.96 & 3.52 & 0.56 & 19.2 & 1.80 & 1.58 & -0.21 & -11.9 & 0.98 \\
Udu & 6.02 & 5.35 & -0.68 & -11.2 & 2.44 & 2.37 & -0.07 & -2.7 & 0.97 \\
\hline Average & 3.10 & 4.03 & 0.93 & 39.6 & 1.74 & 2.06 & 0.32 & 24.5 & 0.86 \\
\hline
\end{tabular}

279 Table 8. Weibull Wind Distribution parameters for outer islands' AWSs (2016 -2018)

\begin{tabular}{|c|c|c|c|c|c|c|c|c|c|}
\hline Station & $\begin{array}{c}\text { Measured } \\
\text { Weibull } \\
A(\mathrm{~m} / \mathrm{s})\end{array}$ & $\begin{array}{c}\text { WRF } \\
\text { Weibull } \\
A(\mathrm{~m} / \mathrm{s})\end{array}$ & $\begin{array}{c}\text { Weibull } \\
A \text { Bias }\end{array}$ & $\begin{array}{c}\text { Bias } \\
\%\end{array}$ & $\begin{array}{c}\text { Measured } \\
\text { Weibull } \\
k\end{array}$ & $\begin{array}{c}\text { WRF } \\
\text { Weibull } \\
k\end{array}$ & $\begin{array}{c}\text { Weibull } \\
k \text { Bias }\end{array}$ & $\begin{array}{c}\text { Bias } \\
\%\end{array}$ & $\begin{array}{c}\text { Weibull } \\
\text { PDF } \\
\text { Correlation }\end{array}$ \\
\hline Koro & 4.47 & 5.02 & 0.55 & 12.4 & 2.06 & 2.57 & 0.50 & 24.7 & 0.95 \\
\hline Levuka & 4.30 & 5.78 & 1.48 & 35.2 & 1.75 & 2.85 & 1.10 & 63.2 & 0.76 \\
\hline Vunisea & 4.66 & 5.10 & 0.44 & 9.6 & 2.02 & 2.03 & 0.01 & 0.5 & 0.99 \\
\hline Viwa & 4.20 & 6.59 & 2.39 & 57.2 & 1.63 & 2.51 & 0.88 & 54.2 & 0.67 \\
\hline Yasawa & 7.19 & 6.64 & -0.56 & -7.6 & 2.61 & 2.88 & 0.27 & 10.3 & 0.98 \\
\hline Average & 4.97 & 5.83 & 0.86 & 21.4 & 2.01 & 2.57 & 0.55 & 30.6 & 0.87 \\
\hline
\end{tabular}

281 The comparison of the Weibull PDFs provides an opportunity to visualise and compare the 282 measured and the modelled wind speed and its frequency of occurrence. Figures $3-6$ present 283 the comparison of the 3-year modelled and the measured Weibull PDFs together with the 10284 years modelled long-term average (WRF LA) for the leeward side, windward side, outer 285 islands and for all the AWSs, respectively. These figures also list the Weibull $A$ and $286 k$ parameters for each PDF.

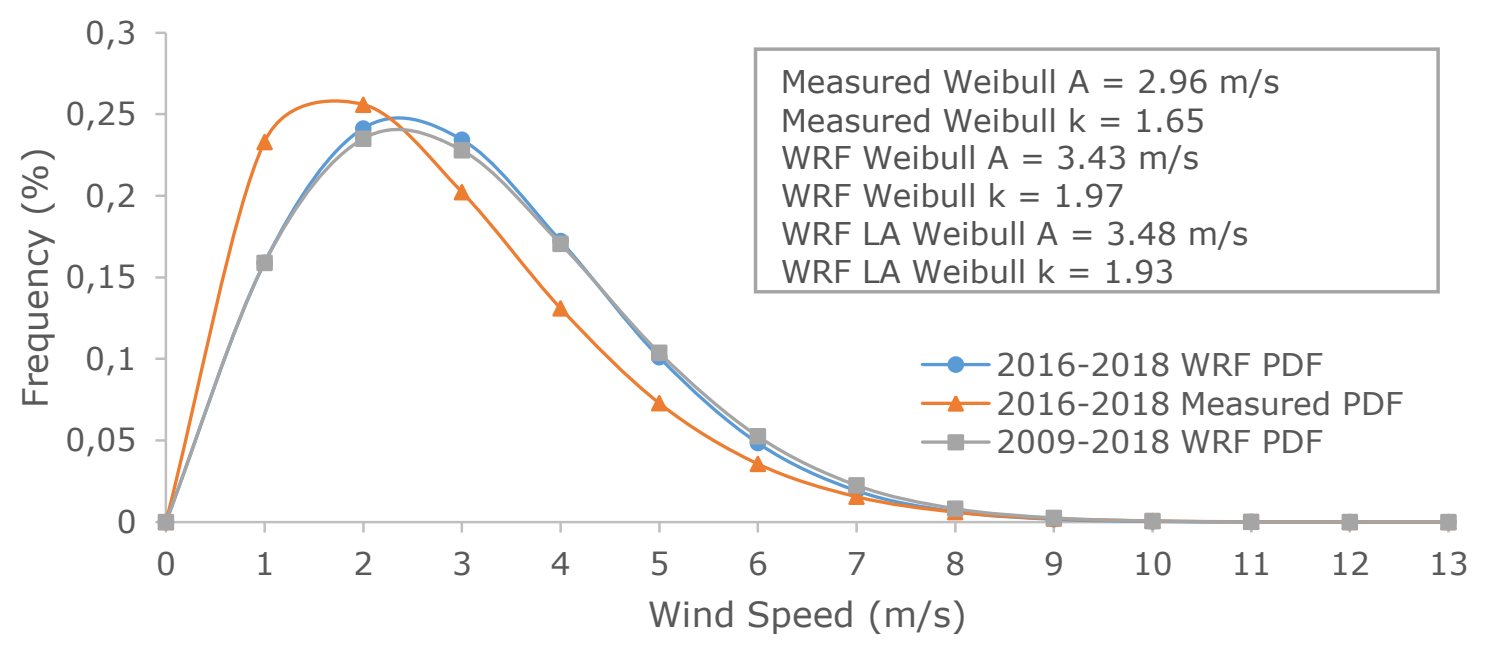

Figure 3. Comparison of the Weibull PDFs for the Leeward Side Stations. 


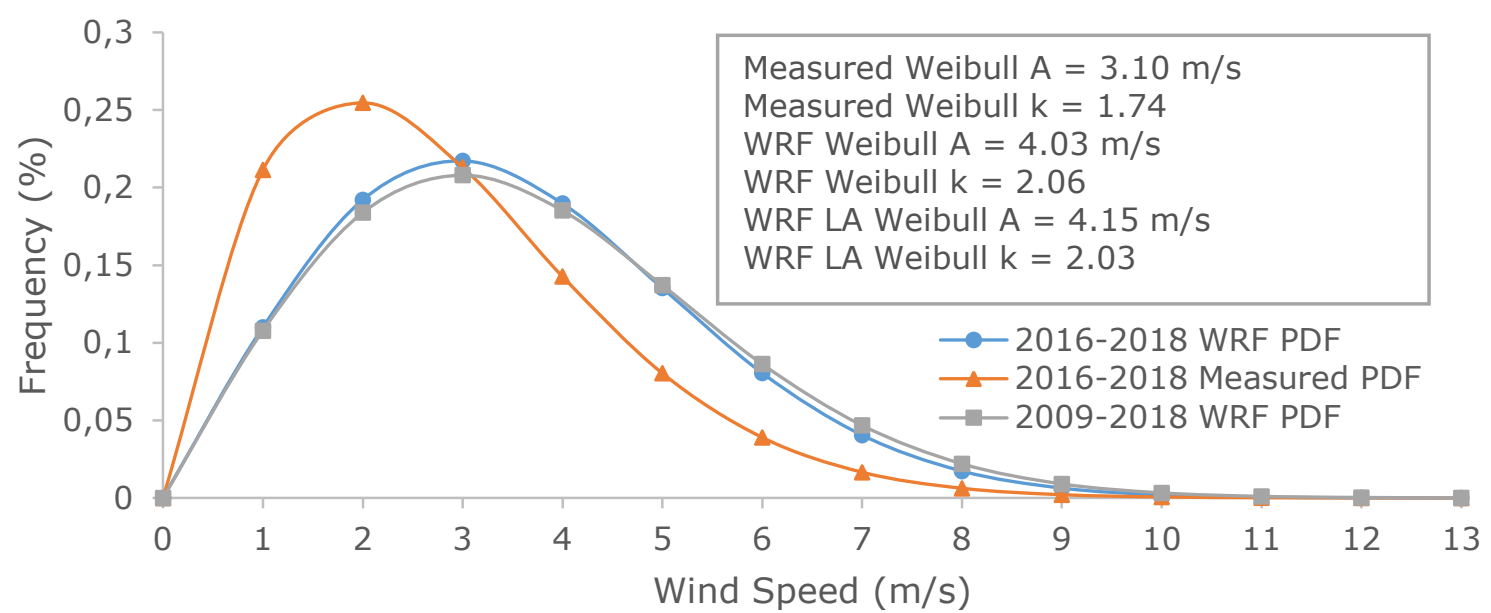

Figure 4. Comparison of the Weibull PDFs for the Windward Side Stations.

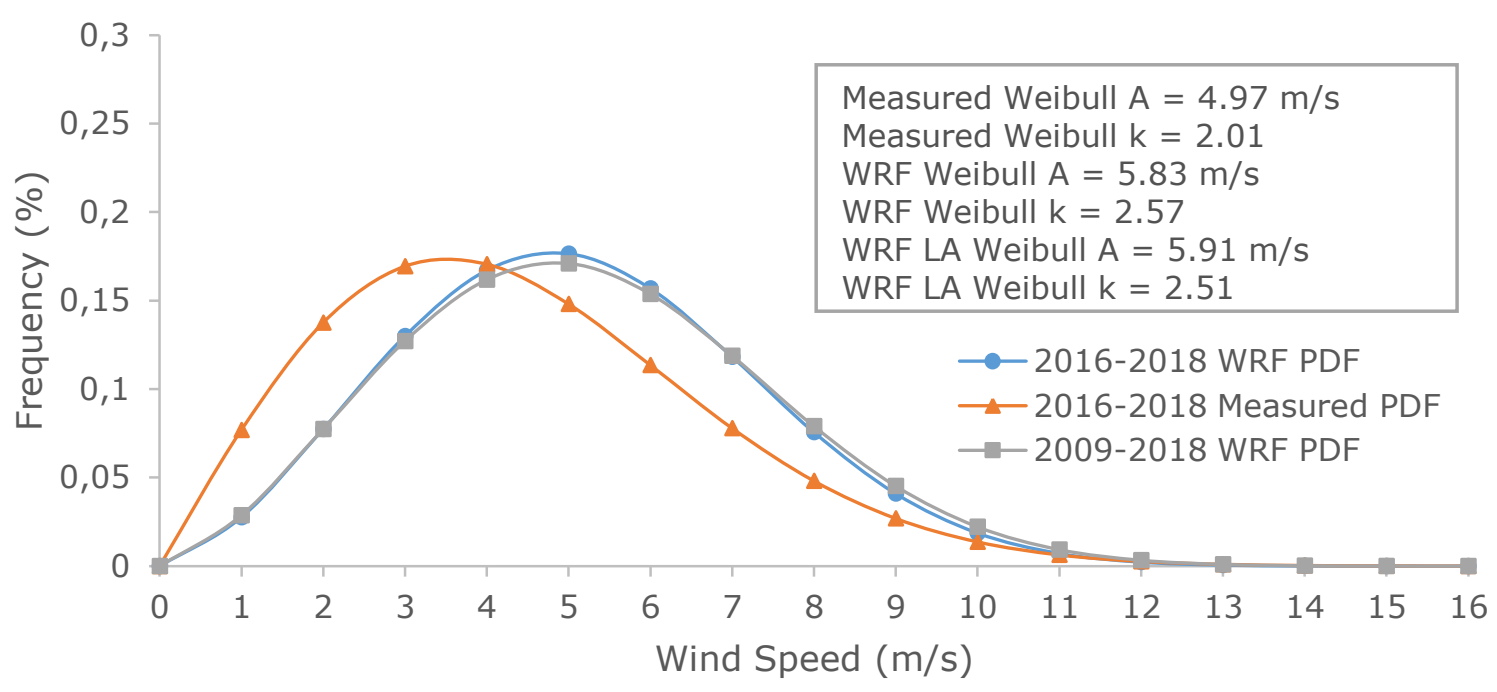

Figure 5. Comparison of the Weibull PDFs for the Outer Islands Stations.

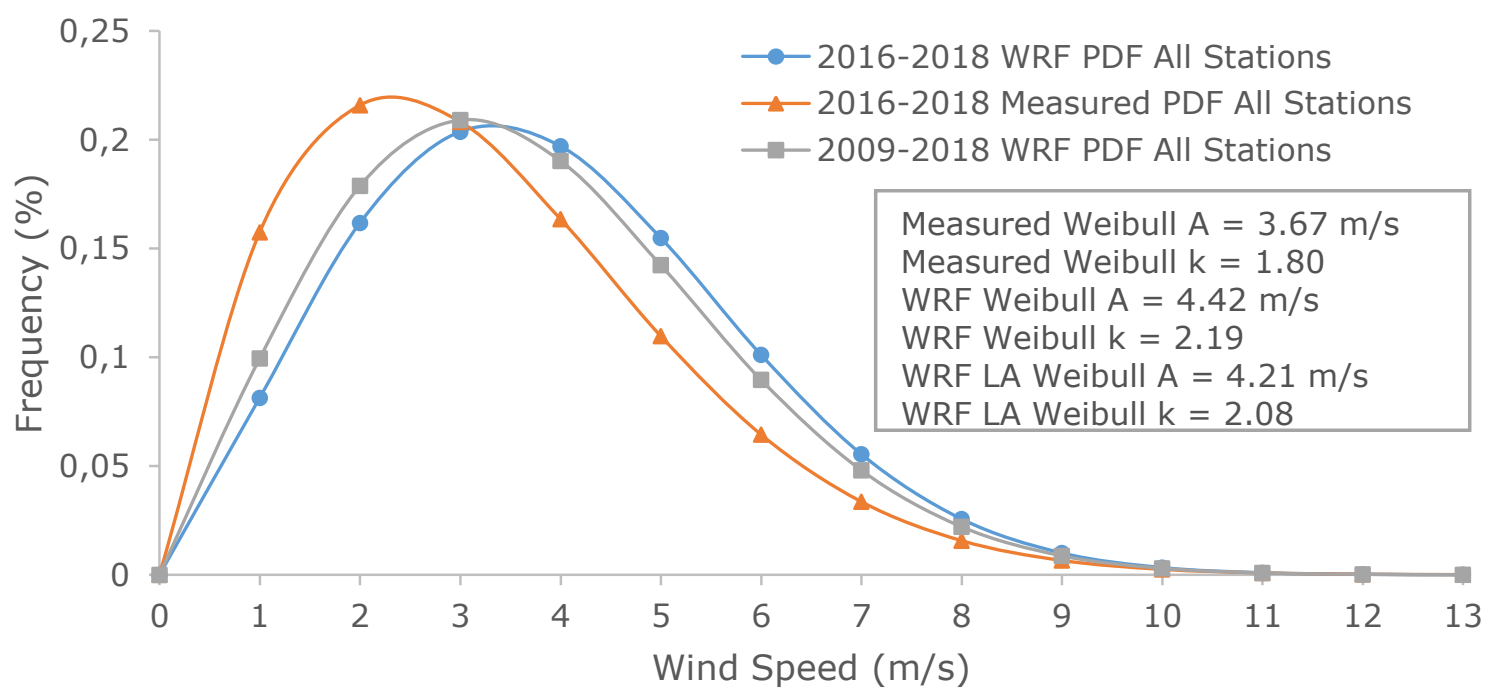

Figure 6. Comparison of the Weibull PDFs for all 24 AWSs. 
295 The comparison between the modelled and observed Weibull PDFs show that the model 296 agrees moderately well with the observations (with an average correlation of 0.88 for 24 297 AWSs). Nonetheless the model tends to record lower frequency of lower wind speeds of 1 -

$2982 \mathrm{~m} / \mathrm{s}$ on the leeward and the windward sides of the larger islands, and $1-3 \mathrm{~m} / \mathrm{s}$ for the outer 299 islands compared with the observations. The opposite is seen for wind speeds from $3-6 \mathrm{~m} / \mathrm{s}$ 300 for the leeward side, $3-8 \mathrm{~m} / \mathrm{s}$ for the windward side, and $5-10 \mathrm{~m} / \mathrm{s}$ for the outer islands. 301 Similar model behaviour is also observed for all the 24 AWSs shown in Figure 6. This 302 indicates that the model tends to overestimate lower wind speeds and underestimate medium 303 to higher wind speeds. The measured Weibull $A$ and $k$ parameters are slightly lower in 304 magnitude than modelled. The mean Weibull PDF correlation across all stations is 0.88 , with 3050.89 for the leeward side, 0.86 for the windward side and 0.87 for the outer islands indicating 306 that the results are in good agreement. The 3-year and the 10-year modelled Weibull PDFs 307 have little variation in terms of the Weibull $A$ and $k$ parameters and the Weibull PDFs 308 correlation is almost 1 , which shows that the 3 -year period is representative of the 10 -year 309 period used in the simulations.

\section{3.1.3 Diurnal Wind Speed Patterns}

311 The diurnal wind speed pattern is the variation of wind speed over a 24-hour period. For a 312 tropical island, it is a representation of the land-sea breeze circulation and provides useful 313 information about the strength of the wind speed during different times of the day. Figures 7 $314-10$ present a comparison of the modelled (WRF) and the measured (M) diurnal wind speed 315 patterns for 3 years together with the 10-year modelled long-term (WRF LA) average for all 316 the AWSs, the leeward side AWSs, the windward side AWSs and the outer islands' AWSs, 317 respectively. Note that the diurnal cycles of individual stations are not included in this paper, 318 but rather an average across all stations, stations on the leeward side, windward side and the 319 outer islands is used. 


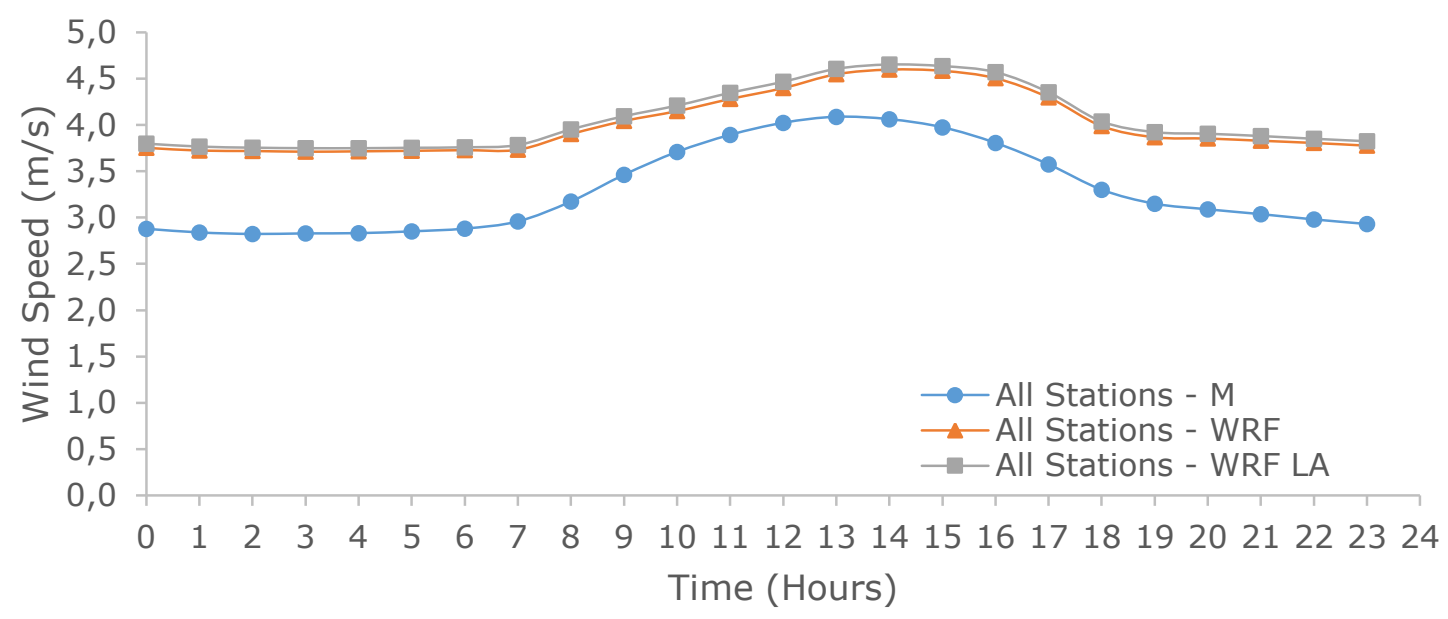

320

321

Figure 7. Diurnal wind speed pattern for all 24 AWSs.

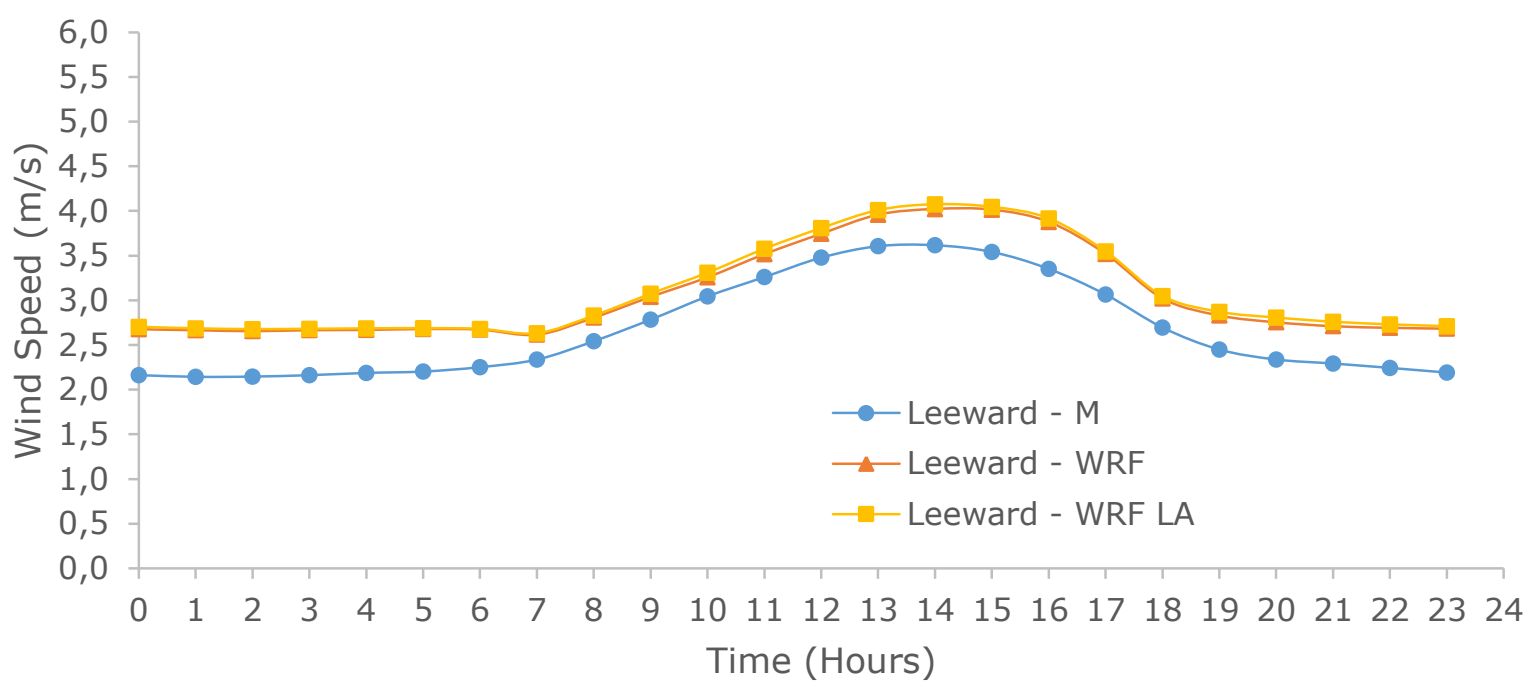

Figure 8. Diurnal wind speed pattern for the Leeward Side AWSs.

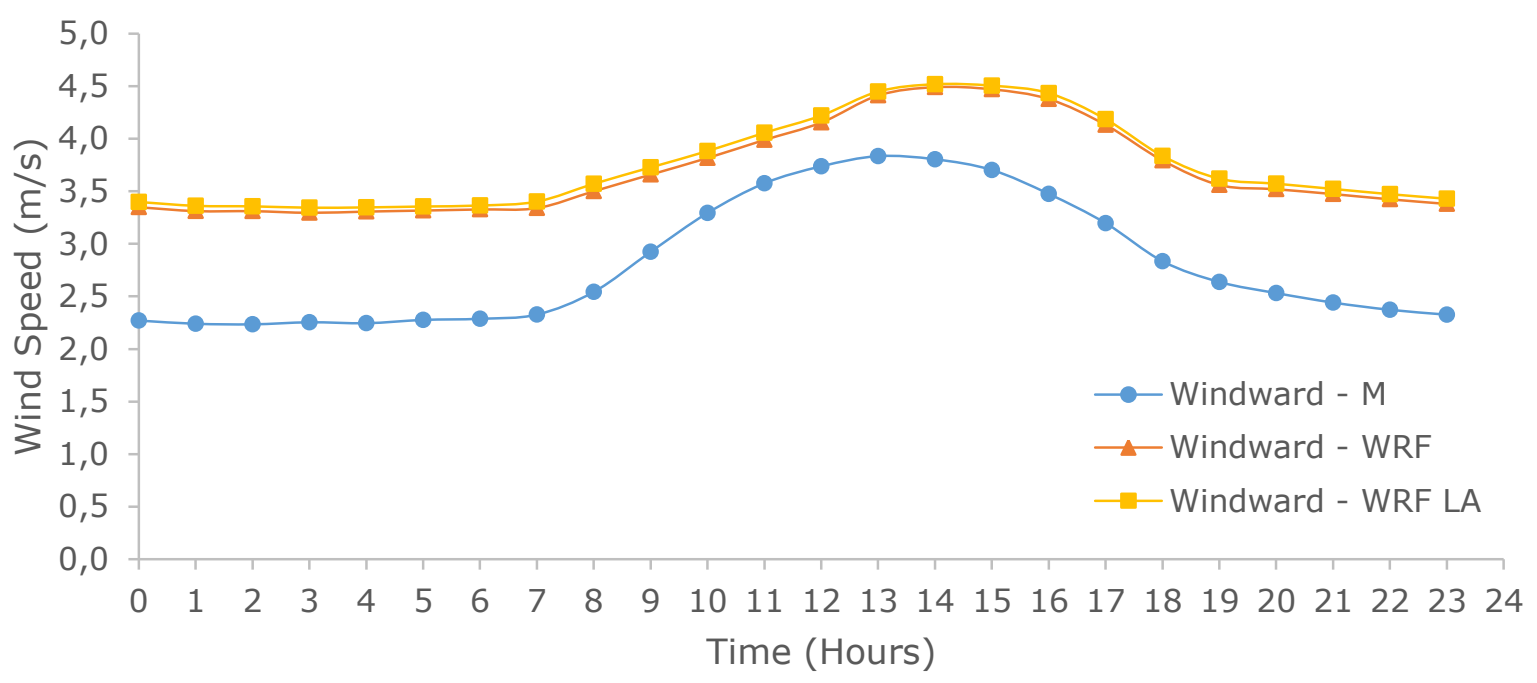

Figure 9. Diurnal wind speed pattern for the Windward Side AWSs. 


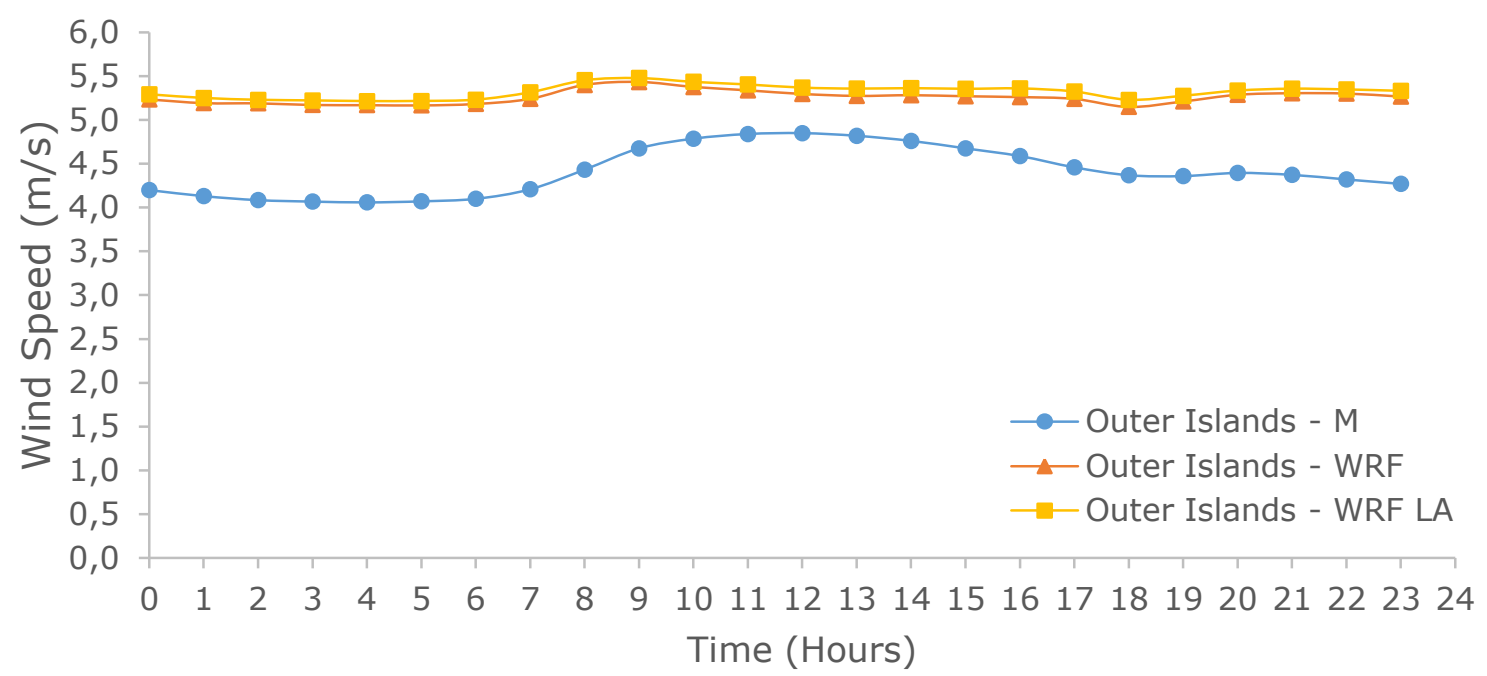

Figure 10. Diurnal wind speed pattern for the Outer Islands AWSs.

The model simulated diurnal cycle for 3 years and 10 years is generally in good agreement with the observations. The overall diurnal cycle for all the 24 AWSs is similar to the diurnal cycles on the leeward and the windward sides. Comparison of the 3 year and the 10-year modelled diurnal cycles shows little variation, with a correlation of almost 1 (Figure 7). The model is able to capture the diurnal cycle patterns for both sides of the larger islands, although it systematically overestimates the wind speed. For the leeward and the windward sides of the larger islands, a strong diurnal cycle is observed and modelled, which can be seen in Figures 8 and 9. For the outer islands, which are relatively smaller, a weaker diurnal cycle is observed (Figure 10), which is expected for small tropical islands as ventilation prevents the genesis of the land-sea breeze circulation [40]. This small observed diurnal cycle is not correctly simulated by the WRF model, which only simulates a small early-morning increase in wind speed. This is probably caused by the lack of representation of small-scale topography in the model, which can reduce the efficiency of the ventilation process. The model performance is better on the leeward-side stations with a smaller estimate of the mean diurnal wind speed in comparison with the windward-side and the outer-islands stations.

\subsubsection{Seasonal Cycle of Wind Speed}

Figures $11-14$ present the comparison of the modelled (WRF) and the measured (M) seasonal cycle of wind speed for the 3-year period together with the 10-year modelled longterm (WRF LA) average for the leeward side, windward side, outer islands and for all the AWSs, respectively. 


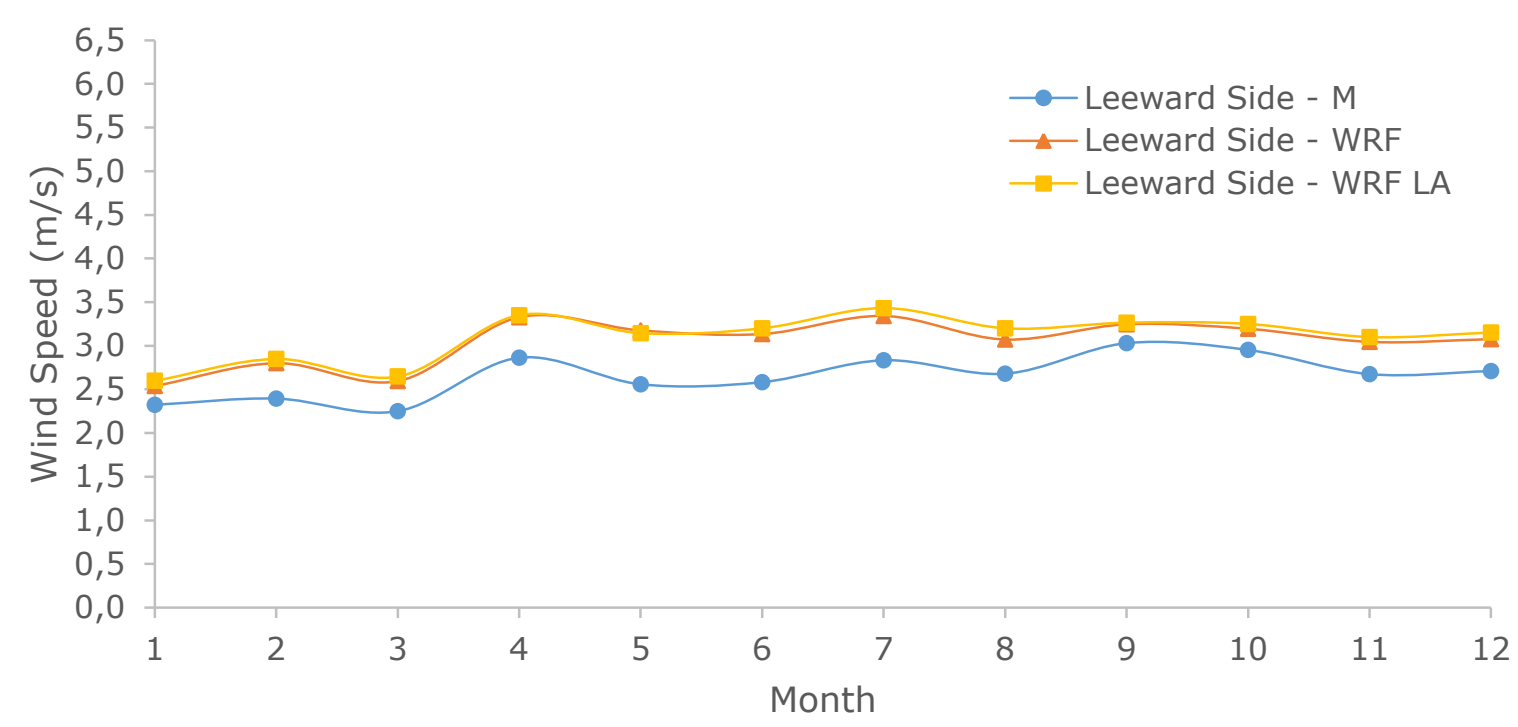

Figure 11. Seasonal cycle of wind speed for the Leeward Side AWS.

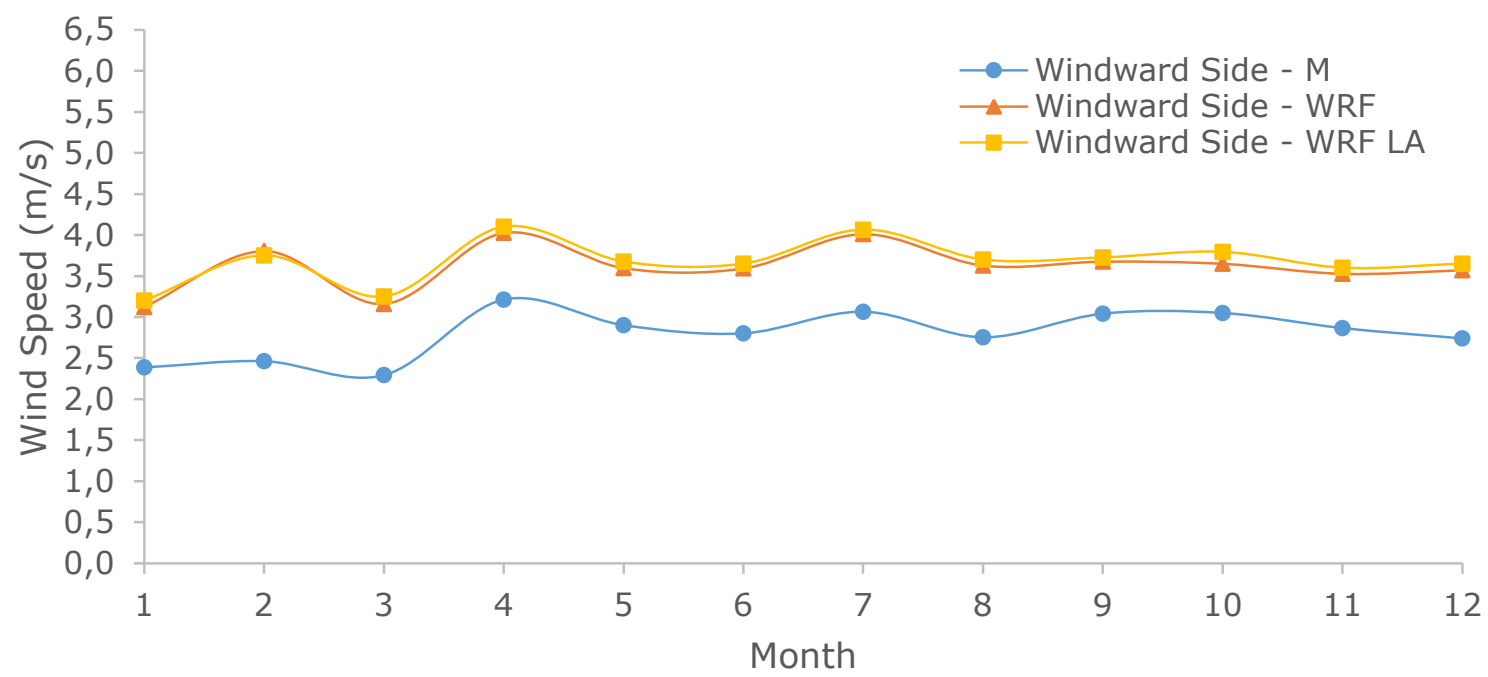

Figure 12. Seasonal cycle of wind speed for the Windward Side AWSs.

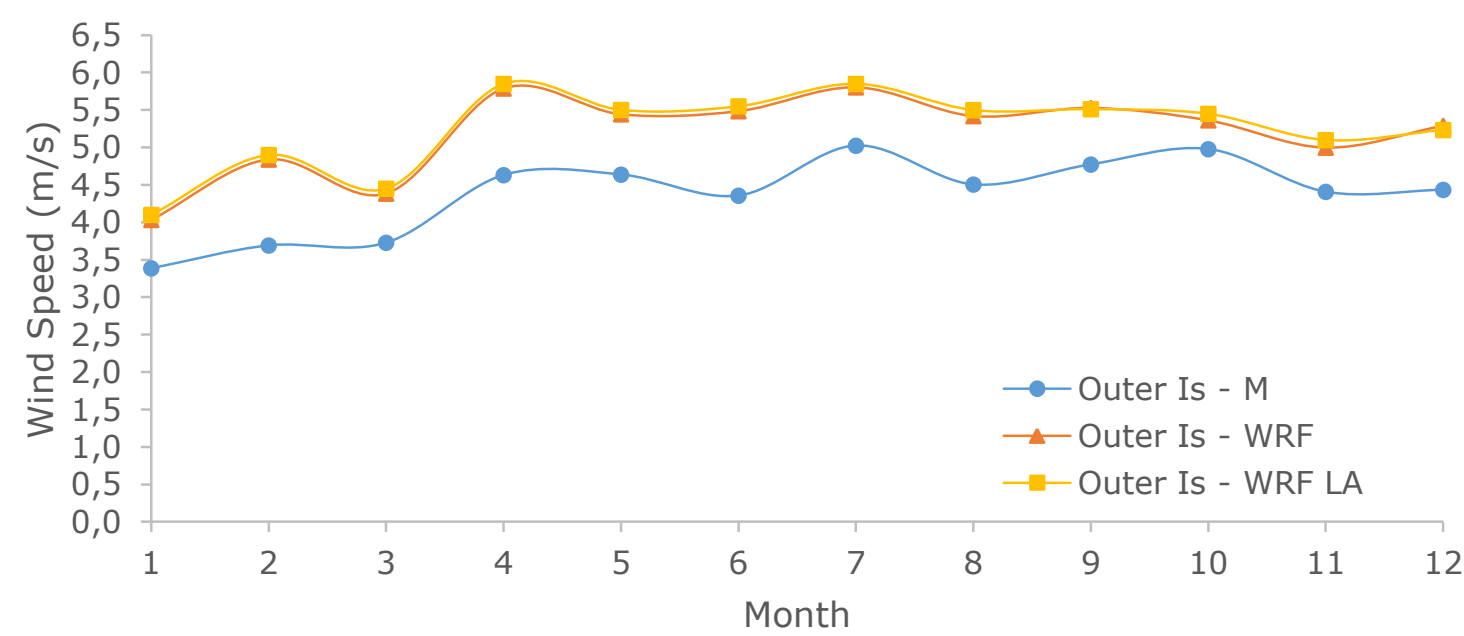

Figure 13. Seasonal cycle of wind speed for the Outer Islands AWSs. 


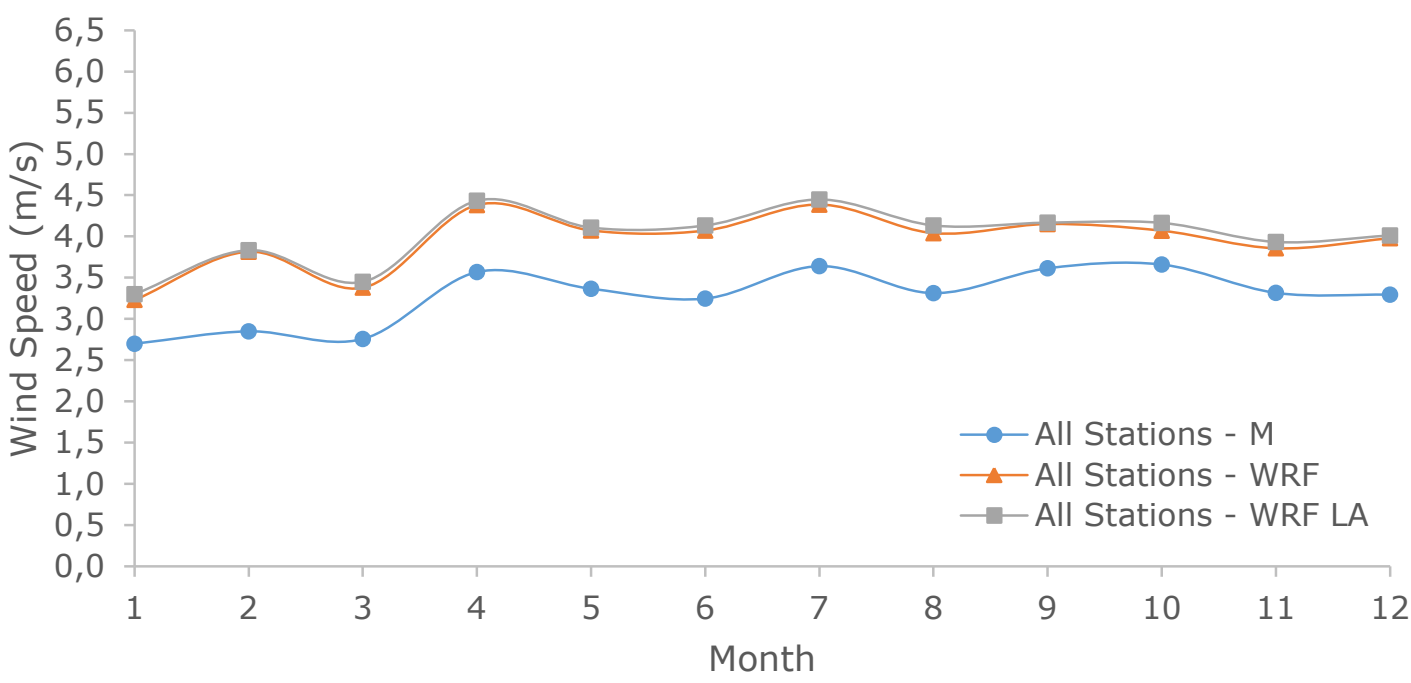

Figure 14. Seasonal cycle of wind speed for all the 24 AWSs.

356 The model-simulated seasonal cycle of wind speed is in good agreement with the

357 observations for the study period. The model successfully captures the seasonal cycle of wind 358 speed for either sides of the larger islands and for the outer islands, although modelled wind speed is overestimated in comparison with the measurements. Again, this overestimation is smaller for the leeward side of the larger islands than for the windward side and the outer islands. A similar model behaviour is observed for the seasonal cycles for all the AWSs. As per the station plots, slightly higher wind speeds are observed during austral winter (May -

363 October), during which the southeast trade winds are more persistent than during austral

364 summer (November to April), during which the wind climatology is mostly dominated by synoptic systems. Little variation can be observed between the 3-year and the 10-year modelled seasonal cycle.

\subsection{Resource Maps}

\subsubsection{Long-term-mean Wind Speed Map at $55 \mathrm{~m}$}

369 The long-term-mean wind speed map represents the spatial distribution of the average wind 370 speed over the simulation. These maps at higher heights such as at the hub-height of a wind 371 turbine are useful for identifying potential wind resource sites that can be used for utility372 scale wind power applications and for siting wind turbines for wind farms. Figure 15 presents 373 the 55-metre-elevation long-term-mean wind speed map for the SIDS of Fiji. Ten years of 374 data was used to calculate the long-term mean. The 55-metre-elevation has been chosen 375 because a typical wind turbine hub height, which is suitable for power generation in the SIDS 
of Fiji, has a hub height of $55 \mathrm{~m}$. Note that wind turbines with a hub-height of $55 \mathrm{~m}$ are

377 employed at the existing Butoni wind farm in Fiji [12].

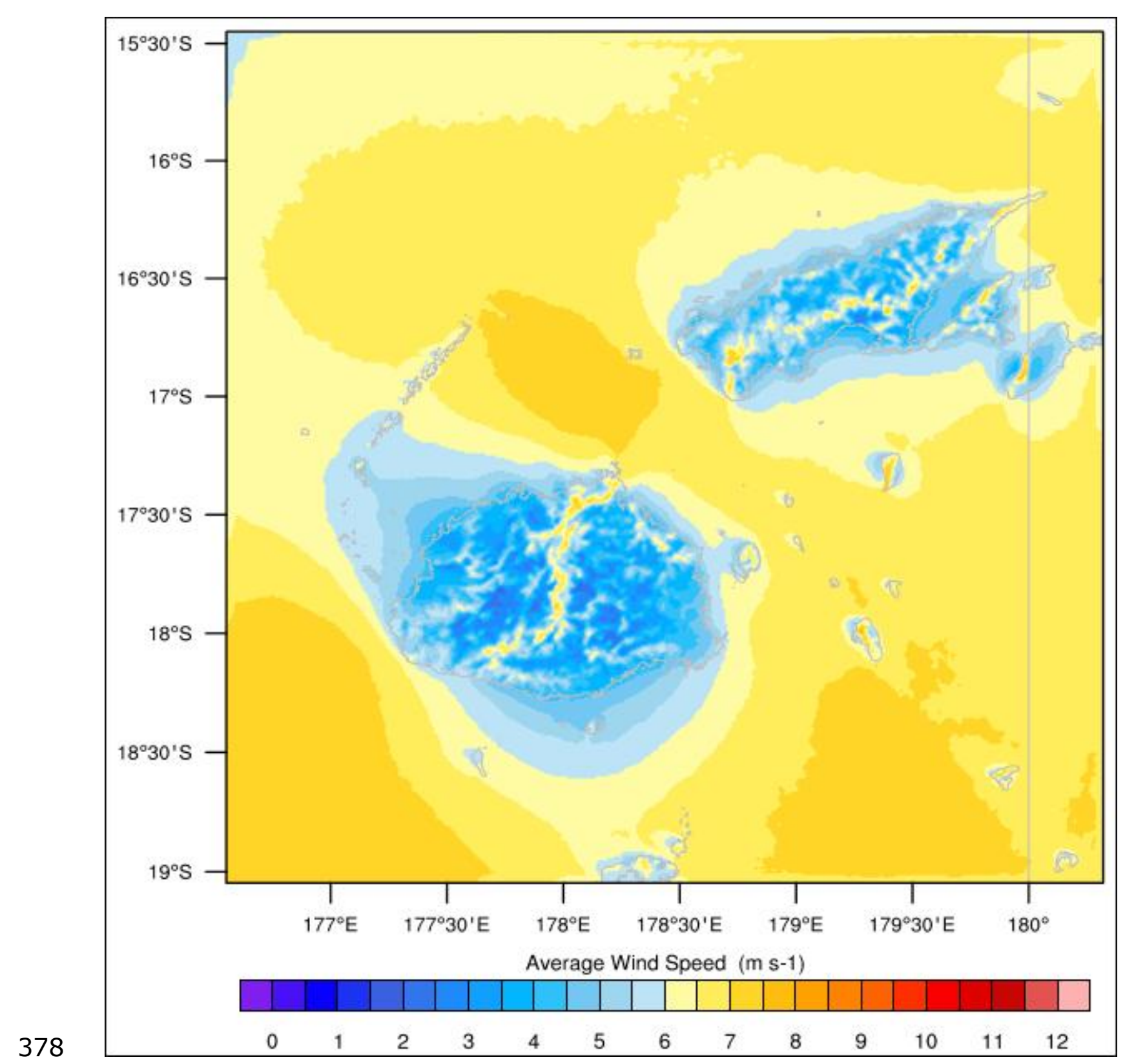

Figure 15. Long-term-mean 55-metre-elevation wind speed map of Fiji.

380 The 10-year average wind speed varies from a minimum of around $1.5 \mathrm{~m} / \mathrm{s}$ to a maximum of $3818 \mathrm{~m} / \mathrm{s}$ over the islands, with minima in the inland valleys and the maxima on the crest of the 382 islands' mountains. The long-term-mean nearshore and offshore wind speed varies from 5 $383 \mathrm{~m} / \mathrm{s}$ to $8 \mathrm{~m} / \mathrm{s}$. The dominant wind direction is south-easterly and the blocking effect of the 384 islands can be seen in their wakes as well as in the upwind flow; this blocking effect means that the flow is diverted around the islands, accelerating the wind on the sides of the islands, particularly in the channel between the two main islands. Following the NREL Wind Power 
387 Classification [41] using the 50-meter-elevation reference, numerous potential wind resource 388 locations on shore can be identified with wind speeds greater than $6.4 \mathrm{~m} / \mathrm{s}$, which corresponds 389 to Wind Power Class 3.

\subsubsection{Seasonal Wind Speed Maps at $55 \mathrm{~m}$}

391 The seasonal wind speed map represents the seasonal spatial distribution of the average 392 hourly wind speed over a season in a year. Figures 16 and 17 present the 55-m-elevation 393 mean seasonal wind speed map of Fiji for the two seasons of austral summer and austral 394 winter calculated using 10 years of data.

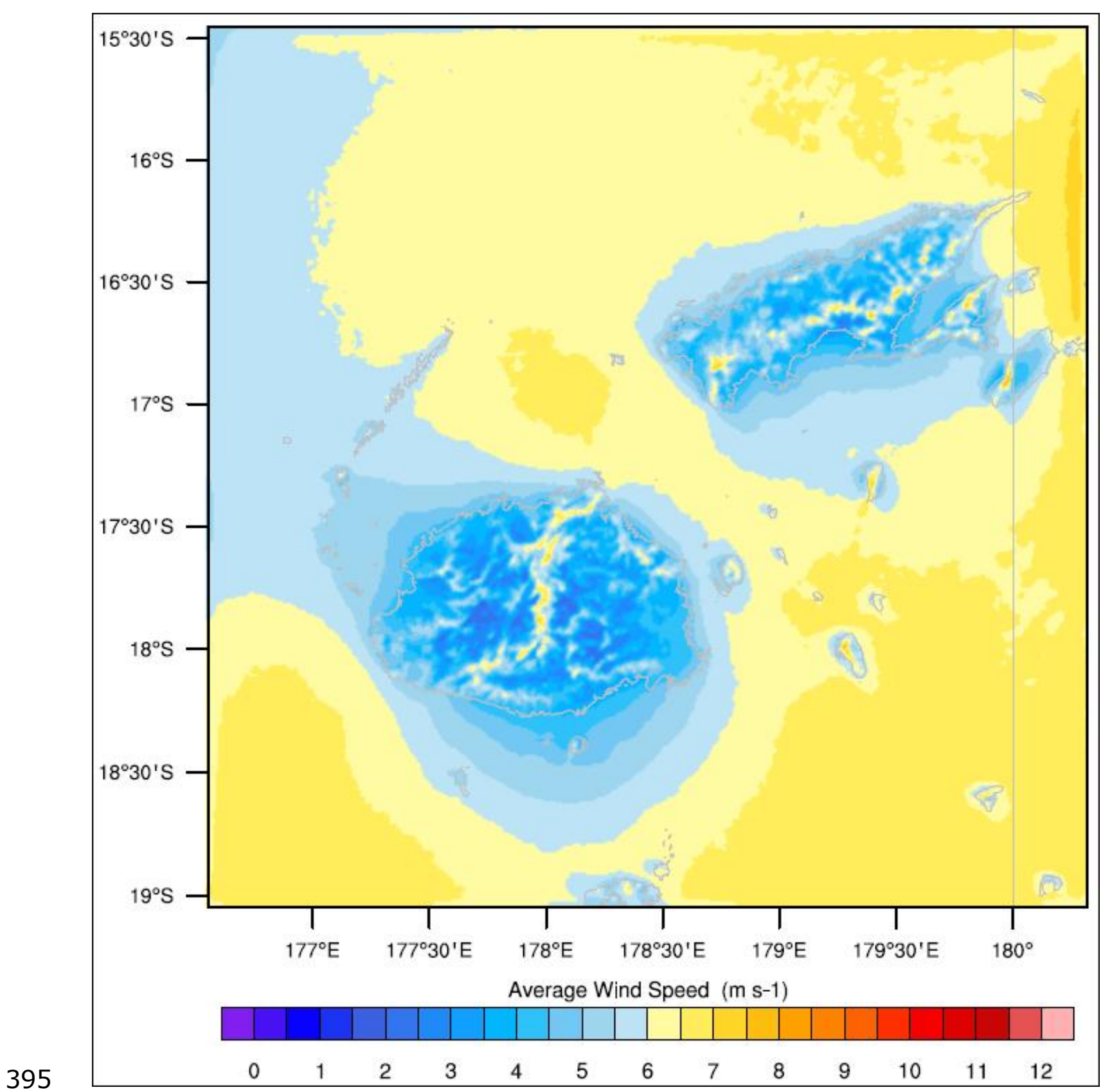

Figure 16. Seasonal 55-metre-elevation wind speed map of Fiji for austral summer. 


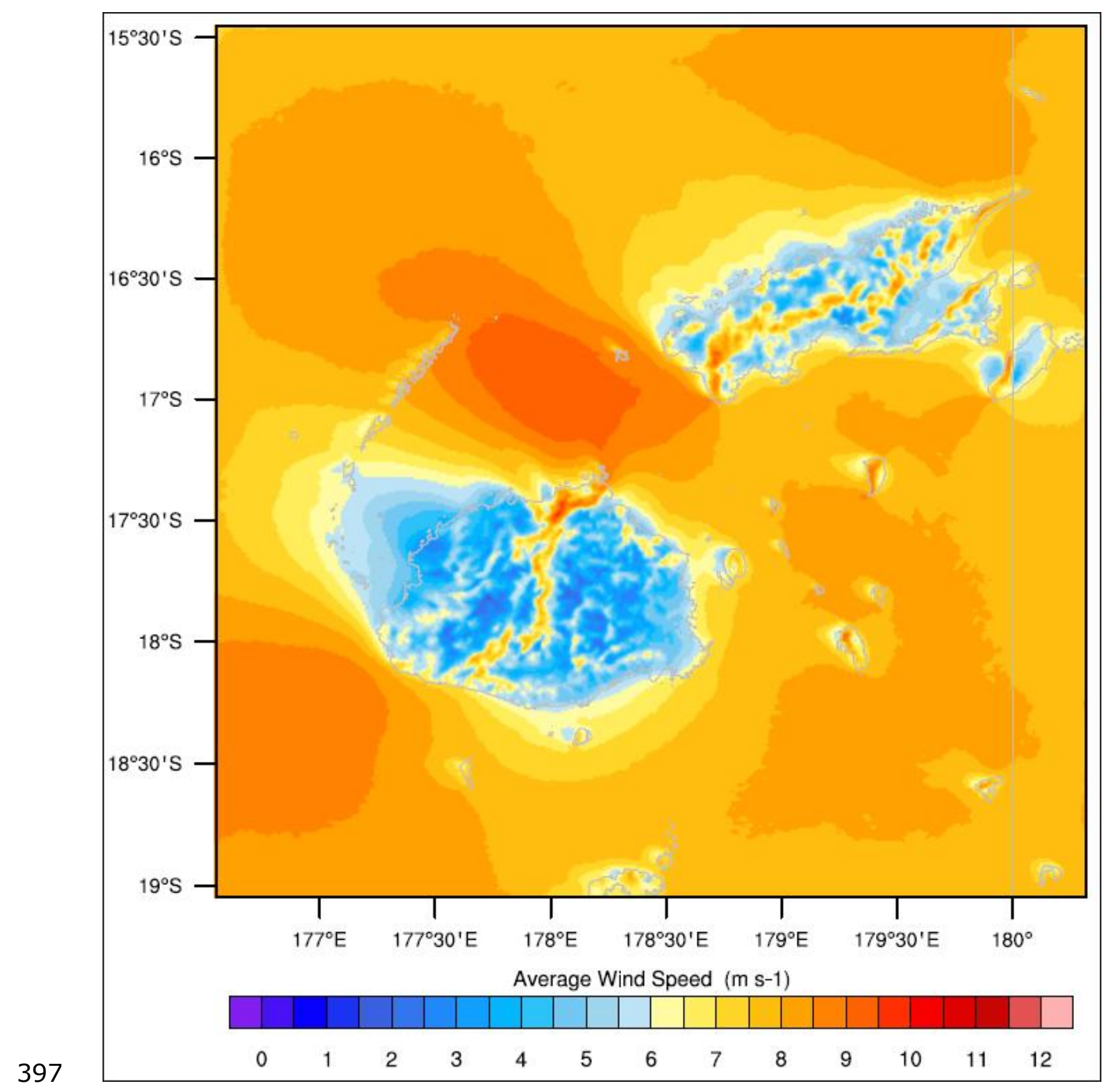

Figure 17. Seasonal 55-metre-elevation wind speed map for austral winter.

399 Higher wind speeds are simulated during austral winter in comparison with austral summer 400 over both onshore land and offshore open sea areas, but the distribution patterns are the same. 401 This seasonal cycle follows that of the large-scale southeasterlies. The seasonal wind speed 402 patterns at 55-metre-elevation essentially identifies the same general wind resource areas as 403 the long-term-mean wind speed map with wind speeds greater than $6.4 \mathrm{~m} / \mathrm{s}$ (Wind Power 404 Class 3) for onshore land areas considered suitable for utility-scale wind power applications 405 using the NREL Wind Power Classification [41]. Note that, these areas are smaller in austral 406 summer. 


\subsubsection{Long-term-mean Wind Power Density Map at $55 \mathrm{~m}$}

409 The long-term-mean wind power density at the hub-height of a wind turbine is also useful in 410 identifying potential wind resource sites for utility-scale wind power applications. Figure 18 411 presents the 55-metre-elevation long-term-mean wind power density map calculated using 10 412 years of data. The plotted values are the wind power density area-averaged over a $1 \mathrm{~km} \times$ $4131 \mathrm{~km}$ grid cell using a constant air density of $1.225 \mathrm{~kg} / \mathrm{m}^{3}$.

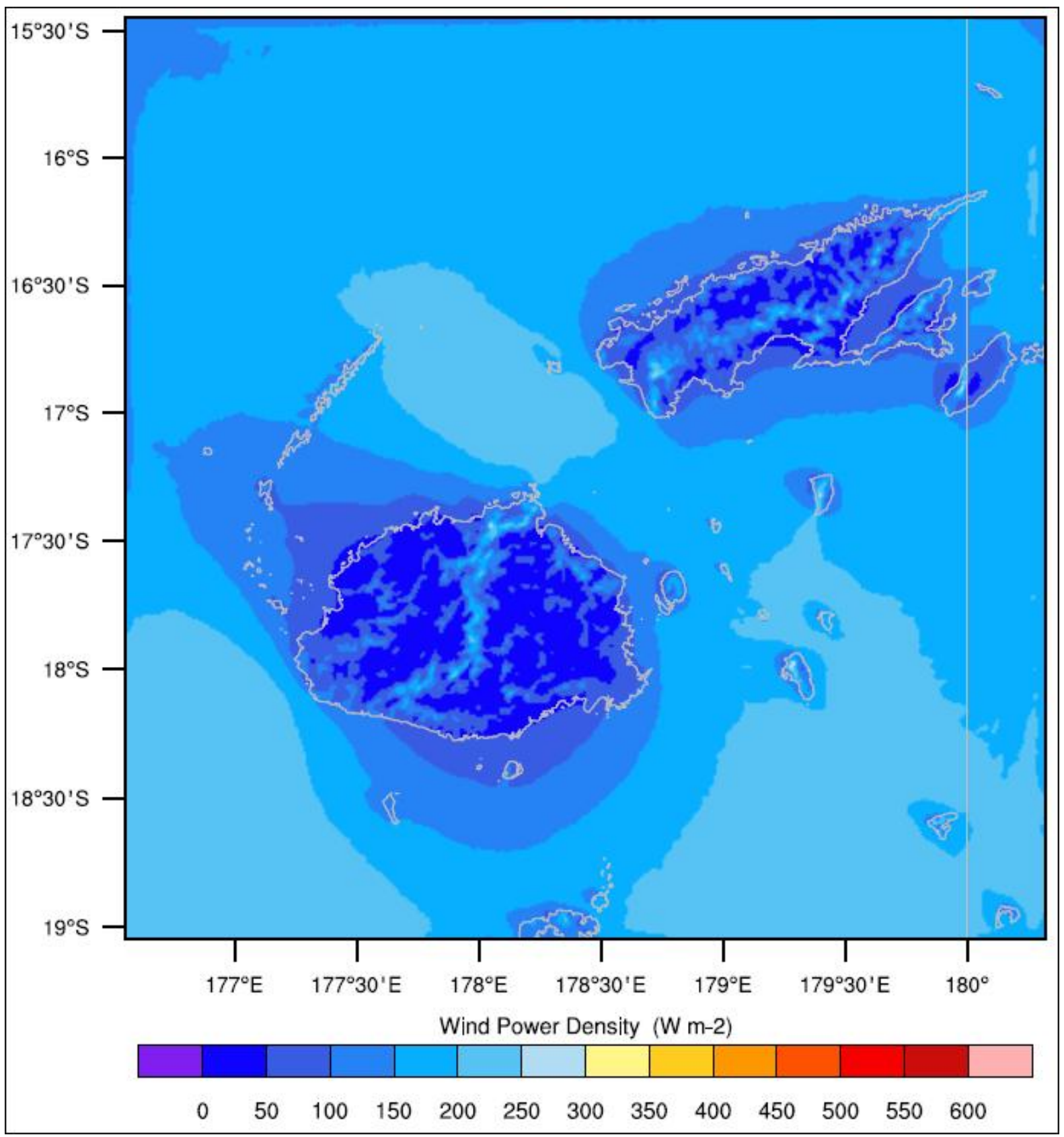

Figure 18. Long-term-mean 55-metre-elevation wind power density map of Fiji. 
416 The 10-year average wind power density varies from $50 \mathrm{~W} / \mathrm{m}^{2}$ to $300 \mathrm{~W} / \mathrm{m}^{2}$ at various

417 locations depending on its topography and geographic location for the onshore land area of

418 the major and the smaller islands. The offshore wind power density varies from $100 \mathrm{~W} / \mathrm{m}^{2}$ to

$419300 \mathrm{~W} / \mathrm{m}^{2}$ from near-shore areas to open sea areas, respectively.

$420 \quad 3.2 .4$ Interannual Wind Speed Variability

421 The interannual wind speed variability refers to the magnitude of fluctuation in the annual

422 mean wind speed on a year-to-year basis at a site. It is an important consideration for the

423 assessment of the long-term wind resource and for the confirmation of the consistency of the

424 wind speed over a time period of multiple years. To evaluate the interannual wind speed

425 variability, the variance of the wind speed anomaly for the model is plotted and the

426 interannual wind speed anomalies for the measured and the modelled wind speed are plotted

427 separately.

428 Figure 19 presents the 10-year mean variance of the 10-metre wind speed anomaly for the 429 model for the 24 AWSs. The variance of the model anomaly varies with a minimum of 0.03 $430 \mathrm{~m} / \mathrm{s}$ at Nadi to a maximum of $2.02 \mathrm{~m} / \mathrm{s}$ at Viwa with an average of $0.68 \mathrm{~m} / \mathrm{s}$ for the 24 AWSs.

431 Eighteen out of twenty-four stations have the variance of the model anomaly less than $1 \mathrm{~m} / \mathrm{s}$.

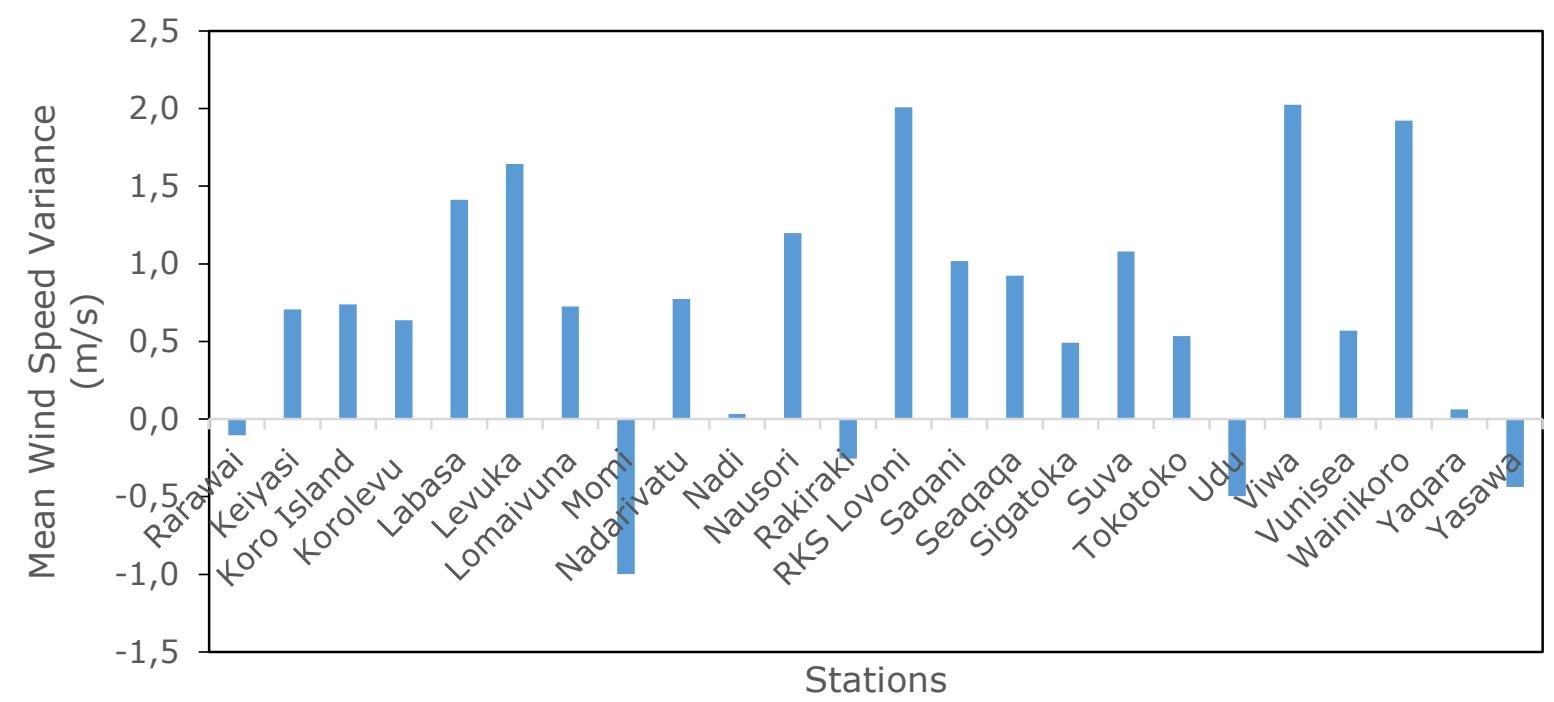
Figure 19. Variance of wind speed anomaly for 10 years for 24 AWSs.

434 The interannual wind speed anomaly of the model and the measurements is the difference 435 between the annual mean and the long-term mean for each. Figures 20 - 22 and Figures 23 43625 present the interannual wind speed anomalies of the measured and model for the 24 AWS 
437 locations for the leeward side, windward side and the outer islands at $10 \mathrm{~m}$ elevation, 438 respectively.

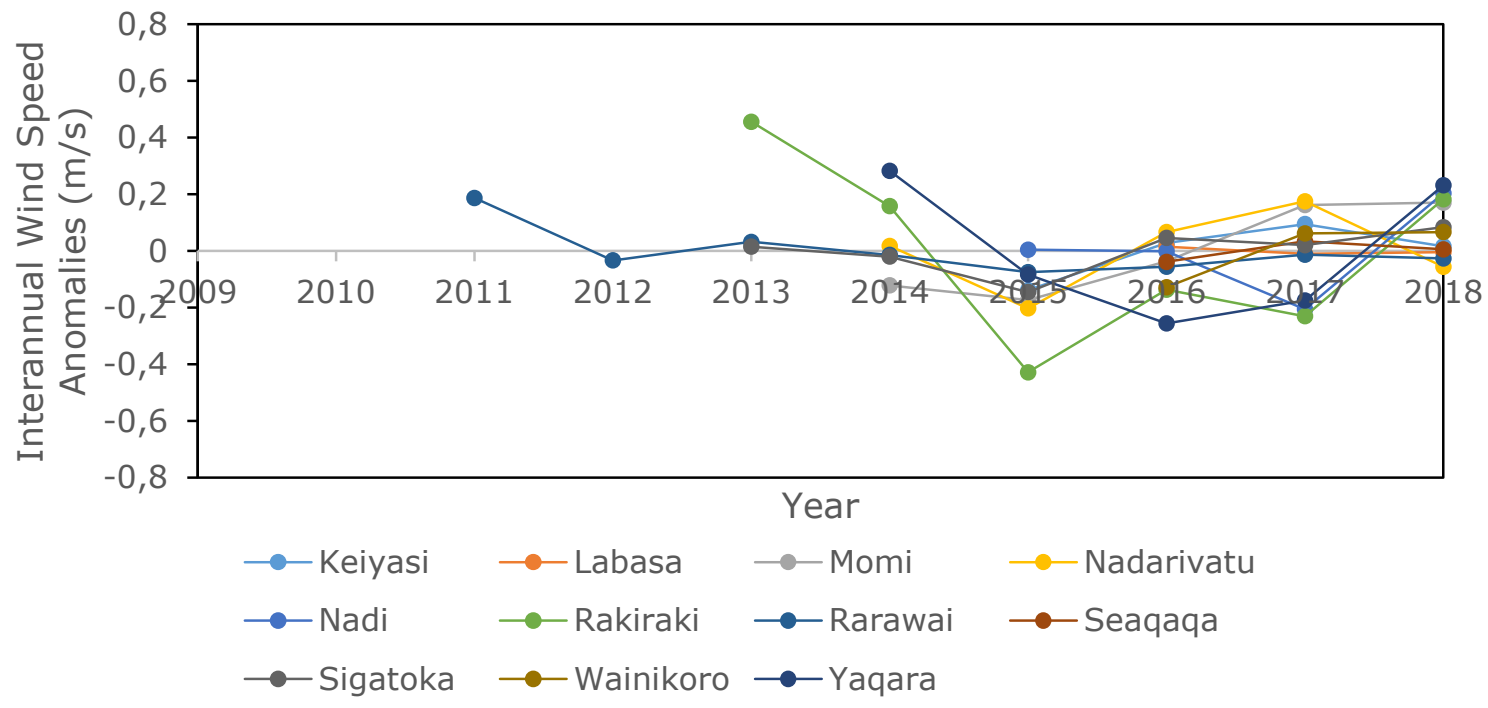

439

Figure 20. Measured interannual wind speed anomalies for the leeward side AWSs.

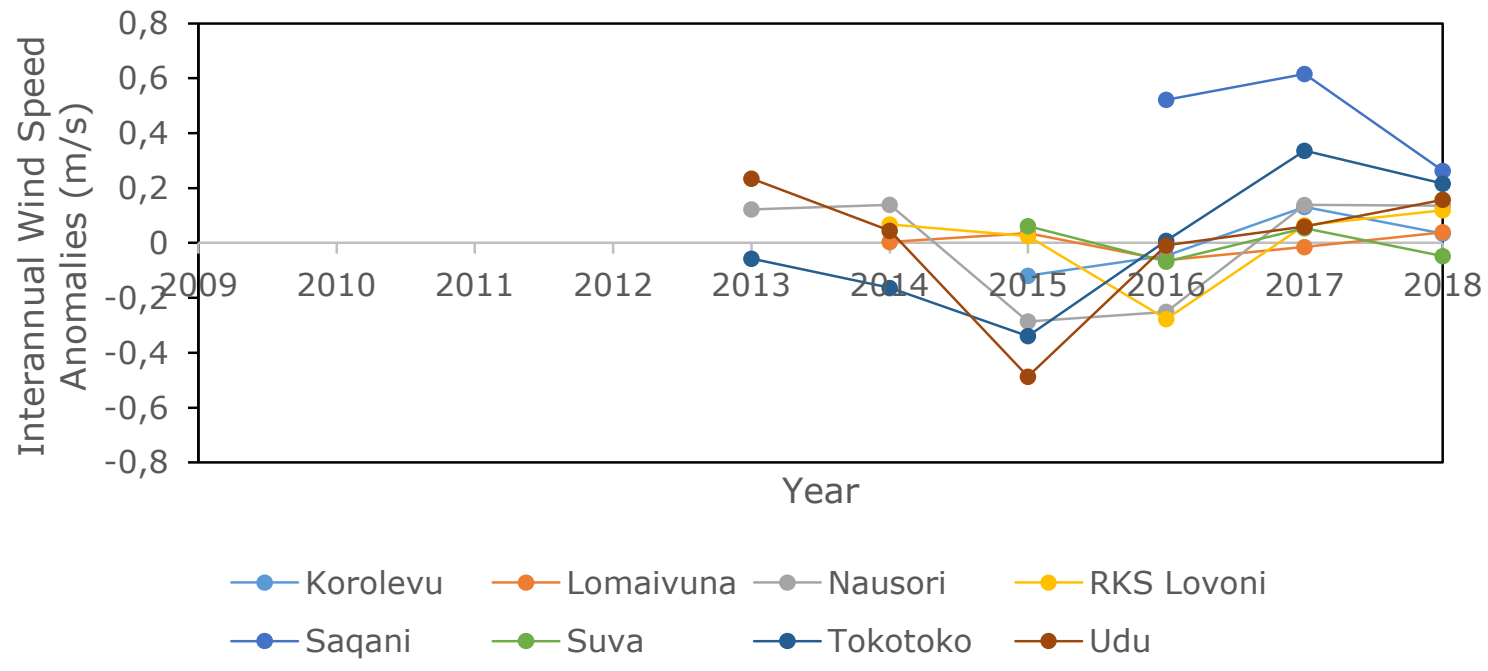

Figure 21. Measured interannual wind speed anomalies for the windward side AWSs. 


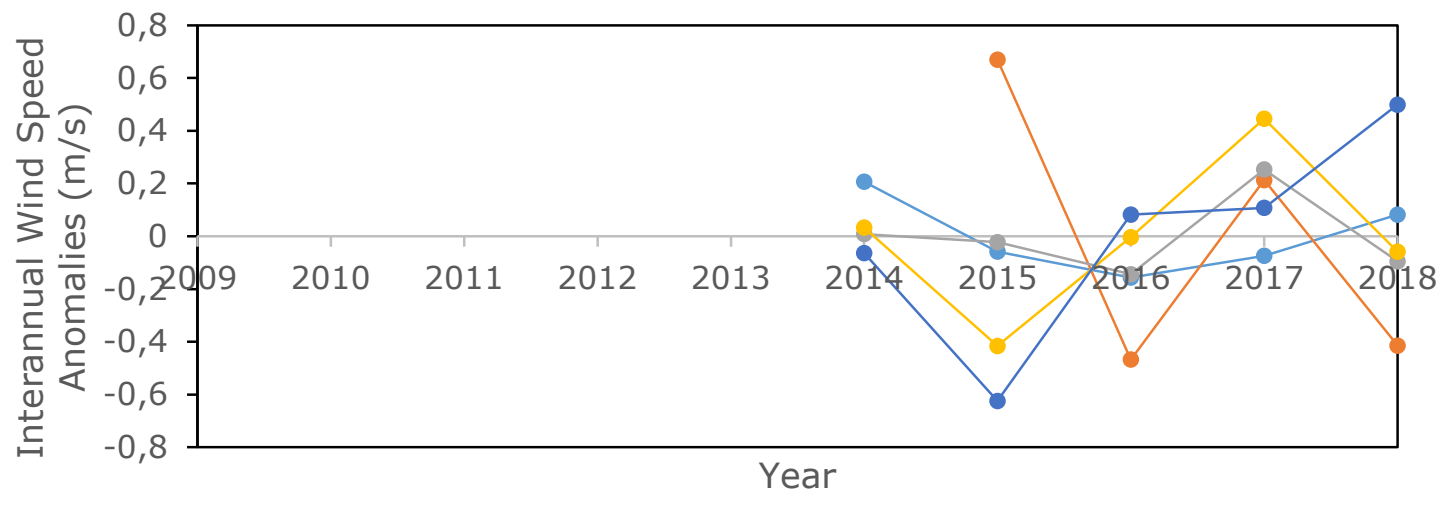

443

$\multimap$ Koro Island $\multimap$ Levuka $\multimap$ Viwa $\multimap$ Vunisea $\multimap$ Yasawa

Figure 22. Measured interannual wind speed anomalies for the Outer Islands AWSs.
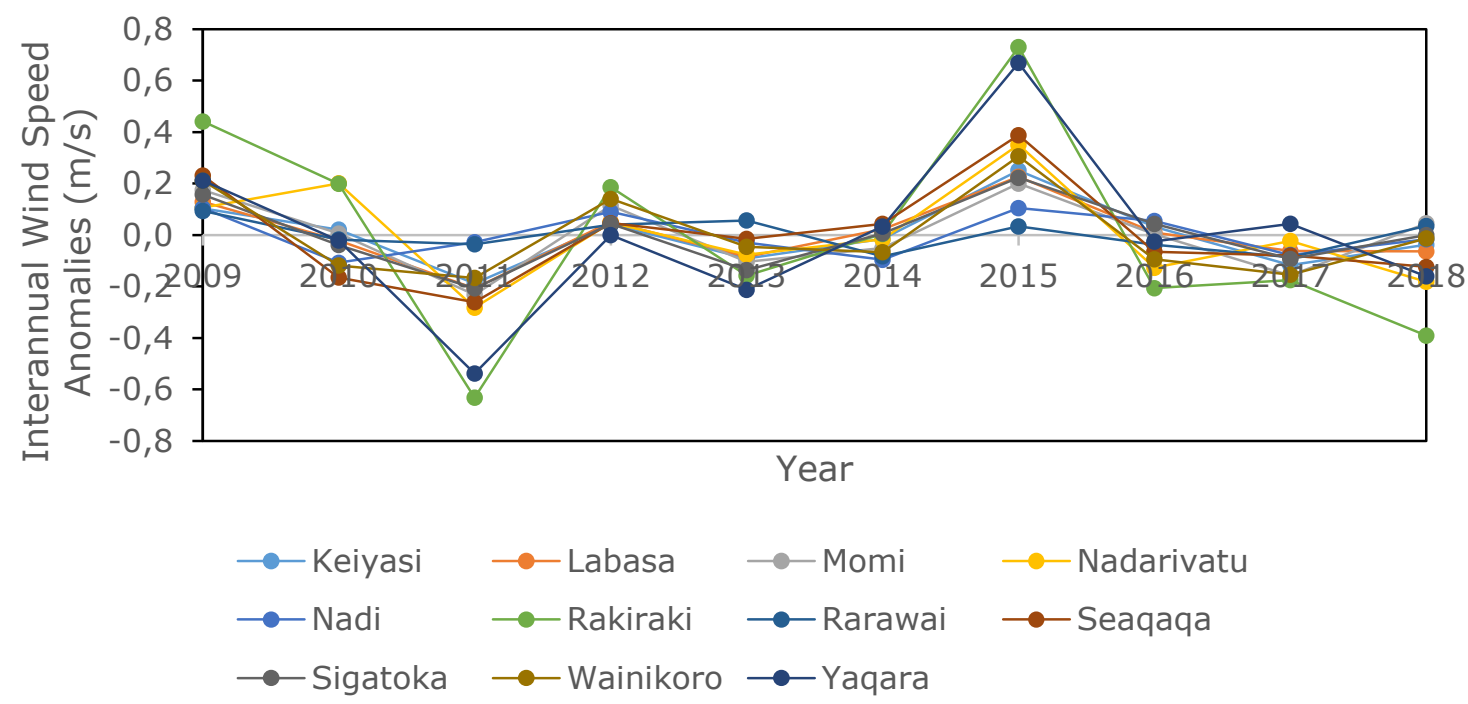

Figure 23. Model interannual wind speed anomalies for the leeward side AWSs.

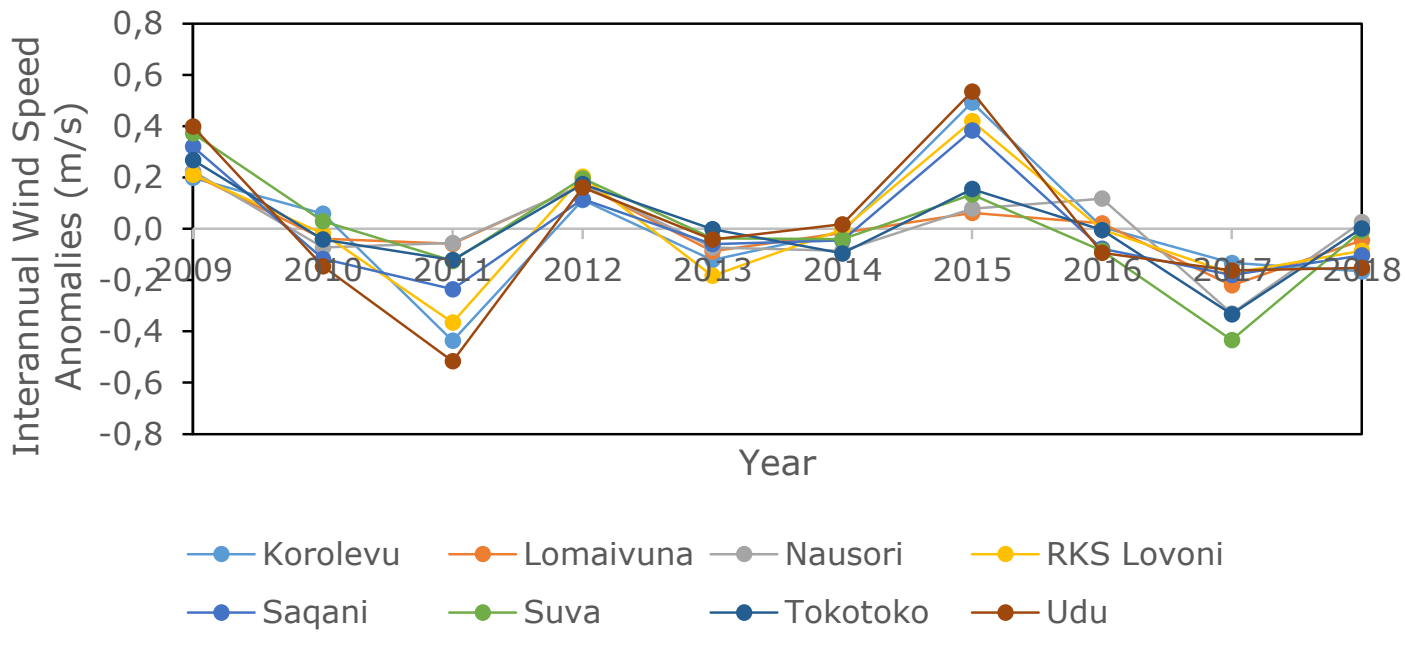

Figure 24. Model interannual wind speed anomalies for the windward side AWSs. 


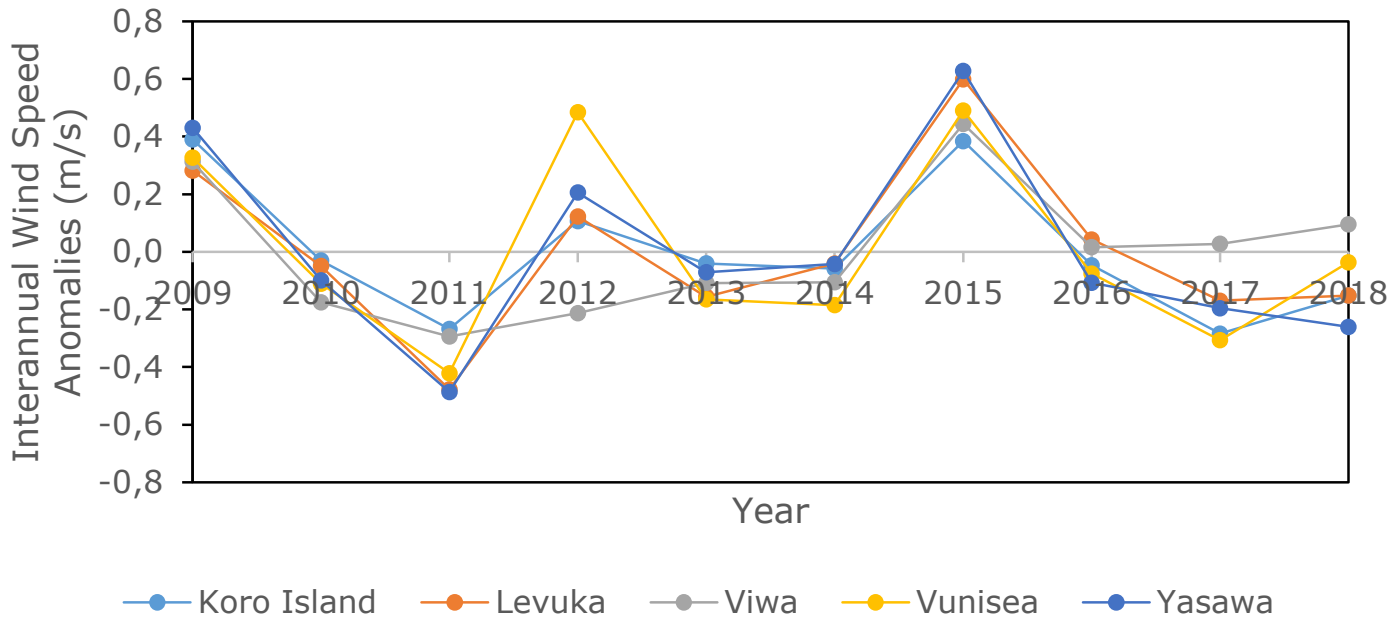

Figure 25. Model interannual wind speed anomalies for the Outer Islands AWSs.

451 The trends in the interannual wind speed anomalies for the model and the measurements on 452 the leeward side, windward side and the outer islands show that there is little variation $(<0.8$ $453 \mathrm{~m} / \mathrm{s}$ ) in the measured and the modelled wind speed over the $3-10$ year period. Since there is 454 little variability in the wind speed, energy production would not change significantly from 455 year to year.

\section{$456 \quad$ 3.2.5 Systematic Bias in Wind Power Density}

457 An evaluation of the systematic bias in wind power density at the 24 AWSs for 3 years is 458 presented in Table 9. This shows the overestimation of the model wind speed. Wind power 459 density is calculated using the measured and the modelled wind speed measurements and the 460 difference is calculated to determine the systematic bias in the 10-metre wind power density 461 at the 24 AWSs. The wind power density (WPD) is calculated using the standard equation 462 (WPD $=\frac{1}{2} \rho V^{3}$, where $\rho$ is the air density and $V$ is the wind speed) with site-specific air 463 density ranging from $1.084 \mathrm{~kg} / \mathrm{m}^{3}$ to $1.168 \mathrm{~kg} / \mathrm{m}^{3}$. The site-specific air density has been 464 estimated using the WAsP Air Density Calculator which is a function of altitude (elevation in 465 metres above sea level) and mean air temperature at the same altitude. A lapse rate of 6.5 $466 \mathrm{~K} / \mathrm{km}$ and a sea level pressure of $1013.25 \mathrm{hPa}$ are assumed and the estimate is based on a 467 standard atmosphere. WAsP software uses the barometric reference data from CFSR reanalysis database [42].

469 The systematic bias computed for wind power density is assumed to be the error in the energy 470 production as it is a function of power density and the other parameters considered in the 471 energy calculation equation are constant. The systematic bias for wind power density is 
472 assumed to be constant with height, as the non-linear relationship of wind power density and

473 wind speed has been considered in the systematic bias at 10-metre elevation. A lower

474 systematic bias can be expected at higher heights for the wind power density in a similar

475 manner to the wind speed bias.

476 The mean systematic bias in the wind power density at the 24 AWSs is $9.68 \mathrm{~W} / \mathrm{m}^{2}$, which is

477 an overestimation of $33.8 \%$. The systematic bias is less than $15 \mathrm{~W} / \mathrm{m}^{2}$ at $13 \mathrm{AWSs}, 15-30$

$478 \mathrm{~W} / \mathrm{m}^{2}$ at 6 AWSs and greater than $30 \mathrm{~W} / \mathrm{m}^{2}$ at $5 \mathrm{AWS}$. Even though it is assumed that the

479 wind speed bias is constant with height, there is a chance that this bias will be smaller at

480 higher elevations as there will be little surface friction at the hub-height of 55-metres in

481 comparison with that at an elevation of 10-metres.

482

483

Table 9. Systematic Bias for Wind Power Density (WPD) for all AWSs at $10 \mathrm{~m}$

\begin{tabular}{lcccccc}
\hline Station & $\begin{array}{c}\text { Measured } \\
\text { Mean }(\mathrm{m} / \mathrm{s})\end{array}$ & $\begin{array}{c}\text { WRF } \\
\text { Mean } \\
(\mathrm{m} / \mathrm{s})\end{array}$ & $\begin{array}{c}\text { D3 }=1 \mathrm{~km} \\
\text { Bias }(\mathrm{m} / \mathrm{s})\end{array}$ & $\begin{array}{c}\text { Measured } \\
\text { WPD }\left(\mathrm{W} / \mathrm{m}^{2}\right)\end{array}$ & $\begin{array}{c}\text { WRF WPD } \\
\left(\mathrm{W} / \mathrm{m}^{2}\right)\end{array}$ & $\begin{array}{c}\text { Bias } \\
\left(\mathrm{W} / \mathrm{m}^{2}\right)\end{array}$ \\
\hline Keiyasi & 1.15 & 1.86 & 0.71 & 0.88 & 3.73 & 2.85 \\
Koro Is & 3.94 & 4.47 & 0.53 & 35.38 & 51.67 & 16.29 \\
Korolevu & 3.30 & 3.88 & 0.58 & 20.95 & 34.05 & 13.10 \\
Labasa & 1.57 & 2.94 & 1.37 & 2.26 & 14.84 & 12.58 \\
Levuka & 3.82 & 5.15 & 1.33 & 32.44 & 79.50 & 47.05 \\
Lomaivuna & 1.98 & 2.61 & 0.63 & 4.49 & 10.28 & 5.79 \\
Momi & 4.14 & 3.20 & -0.94 & 41.30 & 19.07 & -22.23 \\
Nadarivatu & 2.81 & 3.54 & 0.73 & 12.03 & 24.04 & 12.02 \\
Nadi & 2.77 & 2.79 & 0.02 & 12.39 & 12.66 & 0.27 \\
Nausori & 1.94 & 3.08 & 1.14 & 4.26 & 17.06 & 12.80 \\
Rakiraki & 6.10 & 5.53 & -0.57 & 132.56 & 98.76 & -33.80 \\
Rarawai & 1.77 & 1.61 & -0.16 & 3.24 & 2.44 & -0.80 \\
RKS & 2.06 & 3.95 & 1.89 & 5.10 & 35.96 & 30.86 \\
Saqani & 2.80 & 4.17 & 1.37 & 12.80 & 42.27 & 29.48 \\
Seaqaqa & 1.36 & 2.20 & 0.84 & 1.46 & 6.17 & 4.71 \\
Sigatoka & 1.89 & 2.41 & 0.52 & 3.94 & 8.17 & 4.23 \\
Suva & 2.36 & 3.24 & 0.88 & 7.68 & 19.86 & 12.19 \\
Tokotoko & 2.57 & 3.18 & 0.61 & 9.91 & 18.78 & 8.87 \\
Udu & 5.36 & 4.80 & -0.56 & 89.62 & 64.36 & -25.26 \\
Viwa & 3.84 & 5.92 & 2.08 & 33.07 & 121.17 & 88.10 \\
Vunisea & 4.02 & 4.58 & 0.56 & 37.84 & 55.96 & 18.12 \\
Wainikoro & 1.65 & 3.49 & 1.84 & 2.62 & 24.80 & 22.18 \\
Yaqara & 3.98 & 3.93 & -0.05 & 36.79 & 35.42 & -1.37 \\
Yasawa & 6.27 & 5.87 & -0.40 & 143.46 & 117.72 & -25.74 \\
\hline Average & 3.06 & 3.68 & 0.62 & 28.60 & 38.28 & 9.68 \\
\hline & & & & & &
\end{tabular}




\section{Discussion}

486 The modelling exercise using 10 years of data presents an opportunity to quantify and 487 validate the wind-resource for the SIDS of Fiji for the first time at a mesoscale level. The overall model performance is in good agreement with the ground-based measurements. The WRF mesoscale NWP model can successfully reproduce the observed wind climate on the ground. High wind resource areas are identified at higher altitude inland areas of the larger islands of Viti Levu and Vanua Levu, nearshore land areas on the eastern and the western sides of the larger islands and the nearby onshore areas adjacent to the channel between the two larger islands.

Mesoscale wind resource maps of the long-term-mean wind speed and the long-term-mean wind power density at 55-meter-elevation can be compared with the NREL Wind Power

496 Classification [41]. This reveals forty potential wind resource locations with wind speed and 497 power density greater than $6.4 \mathrm{~m} / \mathrm{s}$ and $300 \mathrm{~W} / \mathrm{m}^{2}$ (these values corresponds to Wind Power 498 Class 3 for the 50 metre classification, which is considered feasible for utility-scale wind 499 power applications). For the two main islands of Viti Levu and Vanua Levu where the 500 national electricity grid is available, there are more than $500 \mathrm{~km}^{2}(500 \times 1 \mathrm{~km} \times 1 \mathrm{~km}$ grid 501 cells) of areas on each island where the wind speed and the power density are greater than the 502 Wind Power Class 3 thresholds. Using the rule-of-thumb that $1 \mathrm{~km} \times 1 \mathrm{~km}$ of spatial area is 503 required to site a $10 \mathrm{MW}$ wind farm with $37 \times 275 \mathrm{~kW}$ wind turbines having 5-rotor 504 diameter (160 m) spacing across and downstream using a 6 x 6 array size [43, 44 and 45], the 505 total available potential wind resource area of $1000 \mathrm{~km}^{2}(1000 \times 1 \mathrm{~km} \times 1 \mathrm{~km})$ corresponds 506 to an estimated $1000 \mathrm{MW}$ theoretical potential installed capacity. To confirm this, micro507 siting with a higher resolution model is required to make a decision considering the terrain 508 complexities and the errors associated with the mesoscale modelling.

509 For the smaller outer islands there is also potential for wind power development for rural 510 electrification as the wind resource is available. However, such a development would have to 511 be complimentary to other power systems such as diesel power plants which currently 512 provide electricity in these locations. Outer islands like Gau, Ovalau, Taveuni and Kadavu 513 can accommodate a few MW scale wind farms as there are isolated mini-grid electricity 514 networks, which are mostly supported by diesel power plants and a micro-scale hydropower 515 plant in the case of Taveuni. 
516 Other work has identified outer island sites of Gau [14], Kadavu [20] and Taveuni [17] as 517 potential sites for rural electrification, which the current mesoscale work also identifies.

518 Comparing the results of this study with a recent WAsP microscale wind resource study 519 undertaken by the authors [23], the WRF model is able to successfully identify the three 520 reported potential utility-scale wind farm sites of Rakiraki, Nabouwalu and Udu. Looking at 521 the seasonal cycle of wind speed, the measured and the modelled wind speed seasonal 522 variability is small $(<1 \mathrm{~m} / \mathrm{s})$ over a period of $3-10$ years at all sites where measurements are 523 available. The annual wind speed variability is low because Fiji is situated in the Southeast 524 Trade winds zone, which are steady large-scale winds. The interannual variability is small as 525 well $(\sim 0.8 \mathrm{~m} / \mathrm{s})$. The small natural variability of wind speed guarantees regular energy 526 production.

527 The El-Nino, La-Nina and the ENSO events are the main modes of interannual variability 528 observed on the ground. These are also captured by the model and are the cause of crests and 529 the troughs of the interannual wind speed anomalies in Figures $20-25$. According to the 530 NASA Earth Observatory [46], El-Nino events occurred between 2009 - 2010, 2014 - 2016 531 and 2018 - 2019, La Nina events occurred between 2008 - 2009, 2010 - 2012 and 2017 5322018 and ENSO events occurred between 2014 - 2016.

533 The WRF model has a tendency to overestimate lower wind speeds and underestimate higher 534 wind speeds [34]. The overestimation of wind speed can be observed at the following station 535 locations where the measured wind speed is low: Keiyasi, Labasa, Seaqaqa, Wainikoro, 536 Nausori, Saqani and RKS on the larger islands (\% Bias > $49 \%$ ). The underestimation of 537 wind speed can be observed at Rakiraki, Udu and Yasawa whereby the measured wind 538 speeds are medium to high. Similar model behaviour is reported for studies done for Greece 539 [6] and Hawaii [8].

540 The results generated by numerical weather prediction models are only approximate due to 541 simplifications of the topography and the physical processes which they use in order to make 542 the problem tractable [7]. There is a substantial difference in terms of the wind speed 543 measurements available at 10-metre-elevation from AWSs, which are essentially 544 measurements made at a single point, whereas the wind speeds calculated using the model are 545 the grid cell average which corresponds to an area of $1 \mathrm{~km} \times 1 \mathrm{~km}$. The grid cells are 546 relatively large with an assumed topography and roughness that can be very different from 547 the real conditions [47]. Also, the measurements are made at an elevation of 10-metres, 
548 where structures in the close vicinity might influence the measurements. Such effects are not 549 included in the WRF mesoscale model.

550 There is also a possibility that the stations are out of calibration, as for these sites, the model 551 is able to capture the diurnal cycle pattern, which is similar to the measured and the long-term 552 average diurnal cycles but there is overestimation of wind speed.

553 The terrain representation in the model can also contribute to errors. In Table 1 there are 554 differences in the model and the real elevation at almost all station locations of between -62.4 $555 \mathrm{~m}(-8 \%)$ and $54.4 \mathrm{~m}(170.5 \%)$. For most stations where the topography is less resolved in 556 the model than the real topography, there is an overestimation of wind speed. These include 557 the 6 AWSs mentioned earlier where there is a positive larger difference between the model 558 and the measurements indicating overestimation of wind speed.

559 Significant sources of error in any numerical weather prediction model (such as the WRF 560 model presented in this paper) include: the initial and the boundary conditions (in our case we 561 are using coarse resolution output results from GCMs, which is almost the same for the entire 562 domain as the resolution is around $100 \mathrm{~km} \times 100 \mathrm{~km}$ ); resolution of the domain (in our case 563 it is an average of $1 \mathrm{~km} \times 1 \mathrm{~km}$ ); terrain and vegetation characteristics (in our case we used 564 average values for each $1 \mathrm{~km} \times 1 \mathrm{~km}$ grid cell); nudging and assimilation techniques; and the 565 complexity of the terrain effects and their representation in the model (in our case we have seen differences) [48]. The choice of the physical schemes can also contribute to errors in the

567 model, as these schemes are based on many assumptions, and these assumptions may fail, or 568 give an inadequate response to certain synoptic forcing, limiting their application.

569 In terms of the applicability and value, the finest reanalysis data available globally is ERA5 570 that is available at $31 \mathrm{~km} \times 31 \mathrm{~km}$ grid resolution every hour since 1979, this research created 571 high-resolution wind resource data at $1 \mathrm{~km} \mathrm{x} 1 \mathrm{~km}$ resolution for the recent decade (2009572 2018) for the whole of Fiji, even in locations where ground-based measurements are not 573 available. This data has been used for potential wind resource site identification and to 574 evaluate the theoretical potential of wind energy for Fiji. It can also be used to evaluate the 575 technical potential by coupling it with a microscale model. The advantage of the microscale 576 model (WAsP) is that it uses the wind atlas and generalisation methodology, which removes 577 all the terrain influence from the model data going upwards to the free stream wind speed 578 (geostrophic wind speed) and works downwards taking into account high-resolution terrain 
579 data to create a generalised wind climate which can be used at a predicted site to evaluate the 580 wind resources with greater accuracy then the input data from the model [41].

\section{$581 \quad$ 5. Conclusions}

582 This study presents a high-resolution mesoscale wind-resource assessment of the small island 583 developing state (SIDS) of Fiji using a 10-year simulation of the Weather Research and 584 Forecasting (WRF) model with convection-permitting resolution. Our analysis evaluates the 585 wind speed and Weibull distributions, diurnal and annual wind speed patterns, model 586 statistical analysis, resource maps of annual and seasonal wind speed, power density and 587 interannual wind speed variability and anomalies.

588 The results revealed that the WRF model simulated wind-resource parameters are in good agreement with the observations. The model can be reliably used to simulate the wind flow around the Fijian Islands in order to get reliable information on the wind resource. At $55 \mathrm{~m}$

591 above ground, the annual mean wind speed and wind power density varies from $1.5 \mathrm{~m} / \mathrm{s}$ to 8 $592 \mathrm{~m} / \mathrm{s}$ and $50 \mathrm{~W} / \mathrm{m}^{2}$ to $300 \mathrm{~W} / \mathrm{m}^{2}$, respectively, for onshore land areas. Higher wind speeds are 593 observed during austral winter than in austral summer. Forty high wind-resource areas are 594 identified in this study, which were previously unknown. This indicates that there is potential 595 for utility-scale wind power generation at selected locations with wind speed and power 596 density greater than $6.4 \mathrm{~m} / \mathrm{s}$ and $300 \mathrm{~W} / \mathrm{m}^{2}$ (NREL Wind Power Class 3 at an elevation of 50 $597 \mathrm{~m})$.

598 As the first mesoscale wind resource modelling exercise for the SIDS of Fiji for the recent 599 decade (2009 - 2018), our study supports the idea that the SIDS in the Pacific can utilize their 600 wind-resource to ease its dependence on diesel-based power generation. It also provides a 601 methodology for mesoscale wind-resource assessment for the SIDS in the Southwest Pacific 602 together with the identification and verification of potential wind resource sites.

603 In future work, it is recommended that the WRF model results are coupled with the linear 604 wind flow model WAsP. Such an approach could improve the accuracy of the wind speed 605 prediction by taking into account high-resolution micro-scale features of the topography and 606 vegetation characteristics. This could also assist in determining the accuracy of the wind 607 speed prediction as well as evaluating the wind energy potential for the identified locations 608 from the high-resolution mesoscale wind resource mapping exercise.

\section{Acknowledgement}


610 This study is part of a $\mathrm{PhD}$ research project, for which the lead author is the recipient of 611 scholarship funding from the New Zealand Ministry of Foreign Affairs and Trade 612 (NZMFAT). The authors gratefully acknowledge the Fiji Meteorological Services for 613 providing the ground-based wind data measurements from AWSs in Fiji and the New

614 Zealand eScience Infrastructure (NeSI) for the use of the high-performance computing 615 facilities in this research.

\section{References}

617 [1] REN21. Renewables 2020 Global Status Report (Paris: REN21 Secretariat); 2020.

618 [2] GWEC, Global Wind Energy Council. Global Wind Statistics, 2019. Available at: 619 www.gwec.net. Accessed on July 7, 2020.

620 [3] Brower, M. C. (2012). Wind Resource Assessment: A Practical Guide to Developing a 621 Wind Project. John Wiley \& Sons, Inc., Hoboken, New Jersey.

622 [4] Powers, J. G., Klemp, J. B., Skamarock, W. C., Davis, C. A., Dudhia, J., Gill, D. O., 623 Coen, J. L., Gochis, D. J., Ahmadov, R., Peckham, S. E., Grell, G. A., Michalakes, J., Trahan, 624 S., Benjamin, S. G., Alexander, C. R., Dimego, G. J., Wang, W., Schwartz, C. S., Romine, G. 625 S., Liu, Z., Snyder, C., Chen, F., Barlage, M. J., Yu, W., \& Duda, M. G. (2017). The Weather 626 Research and Forecasting Model: Overview, System Efforts, and Future Directions, Bulletin 627 of the American Meteorological Society, 98(8), 1717-1737.

628 [5] A De Meij, J.-F. Vinuesa, V. Maupas, J. Waddle, I. Price, B. Yaseen, A. Ismail (2016). 629 Wind energy resource mapping of Palestine, Renewable and Sustainable Energy Reviews, 56, $630 \quad 551-562$.

631 [6] Theodore M. Giannaros, Dimitrios Melas, Ioannis Ziomas (2017). Performance 632 evaluation of the Weather Research and Forecasting (WRF) model for assessing wind 633 resource in Greece, Renewable Energy, Volume 102(A), 190-198.

634 [7] Carvalho, D. \& Rocha, A. \& Santos, C. Silva \& Pereira, R. (2013). Wind resource 635 modelling in complex terrain using different mesoscale-microscale coupling techniques, 636 Applied Energy, Elsevier, vol. 108(C), 493-504.

637 [8] D. Argüeso, S. Businger (2018). Wind power characteristics of Oahu, Hawaii, Renewable 638 Energy, Volume 128, Part A, 324-336.

639 [9] N. Salvação, C. Guedes Soares (2018). Wind resource assessment offshore the Atlantic 640 Iberian coast with the WRF model, Energy, 145, 276-287. 
641 [10] Chana Chancham, Jompob Waewsak, Yves Gagnon (2017). Offshore wind resource 642 assessment and wind power plant optimization in the Gulf of Thailand, Energy, 139, 706643731.

644 [11] Talam Enock Kibona (2020). Application of WRF mesoscale model for prediction of 645 wind energy resources in Tanzania, Scientific African, 7, 2468-2276.

646 [12] EFL, Energy Fiji Limited. Annual Report, 2019. Available at: www.efl.com.fj. Accessed 647 on July 7, 2020.

648 [13] Government of Fiji, 2015. Fiji's Intended Nationally Determined Contribution. 649 Available at: http://www4.unfccc.int. Accessed on July 7, 2020.

650 [14] Singh, R.A. (2015). A Pre-feasibility Study of Wind Resources in Vadravadra, Gau 651 Island, Fiji. Energy and Environmental Engineering, 3(1), 5-14.

652 [15] Kumar, A. and Nair, K. (2014). Wind energy potential, resource assessment and 653 economics of wind power around Qamu, Navua, Fiji. International Journal of Wind and 654 Renewable Energy, 3(1), 1-6.

655 [16] Kumar, A. and Nair, A. (2013). Wind power potential at Benau, Savusavu, Vanua Levu, 656 Fiji. International Journal of Energy, Information and Communications, 4(1), 51-62.

657 [17] Kumar, A. and Nair, K. (2012). Wind characteristics and energy potentials at Wainiyaku 658 Taveuni, Fiji. Management of Environmental Quality: An International Journal, 23 (3), 300659308.

660 [18] Kumar, A. and Prasad, S. (2010). Examining wind quality and power prospects on Fiji 661 Islands. Renewable Energy, 35 (2), 536-540.

662 [19] Gosai, A.D. (2015). Wind energy potential and electricity generation at Rokavukavu, 663 Rakiraki in Fiji. MSc Thesis, University of the South Pacific.

664 [20] Sharma, K. and Ahmed, M.R. (2016). Wind energy resource assessment for the Fiji 665 Islands: Kadavu Island and Suva Peninsula, Renewable Energy, 89, 168-180.

666 [21] Pratap, R.D. (2016). Wind/Diesel hybrid micro-grid for a remote Fijian village. MSc 667 Thesis, University of the South Pacific.

668 [22] Dayal, K.K. (2015). Offshore wind resource assessment, site suitability and Technology 669 selection for Bligh Waters Fiji using WindPRO. MSc Dissertation, Uppsala University. 
670 [23] Dayal, K. K., Cater, J. E., Kingan, M. J., Bellon, G. D. and Sharma, R. N. (2021). Wind 671 resource assessment and energy potential of selected locations in Fiji. Renewable Energy, $672172,219-237$.

673 [24] Dayal, K. K., Cater, J. E., Kingan, M. J., Bellon, G. D. and Sharma, R. N. (2020). 674 Evaluating of the WRF model for simulating the surface winds and the diurnal cycle of wind 675 speed for the small island state of Fiji. Journal of Physics: Conference Series, 1618, 062025.

676 [25] Dayal, K. K., Cater, J. E., Kingan, M. J., Bellon, G. D. and Sharma, R. N. (2020). A grid 677 sensitivity study of the Weather Research and Forecasting (WRF) model for simulating the 678 surface winds for the small island state of Fiji. $22^{\text {nd }}$ Australasian Fluid Mechanics Conference 679 AFMC 2020, Brisbane, QLD Australia, 7-10 December 2020.

680 [26] Skamarock, W. C., Klemp, J. B., Dudhia, J., Gill, D. O., Barker, D. M., Duda, M. G., 681 Huang, X. Y., Wand, W. and Powers, J. G. (2008). A Description of the Advanced Research 682 WRF Version 3. NCAR Technical Note, NCAR/TN-475+STR.

683 [27] Wang, W., Bruyere, C., Duda, M., Dudhia, J., Gill, D., Kavulich, M., Keene, K., Chen, 684 M., Lin, H-C., Michalakes, J., Rizvi, S., Zhang, X., Berner, J., Ha, S. and Fossell, K. (2018). 685 WRF-ARW User Guide V3.9.

686 [28] Horvath, K., Koracin, D., Vellore, R., Jiang, J., and Belu, R. (2012). Sub-kilometer 687 dynamical downscaling of near-surface winds in complex terrain using the WRF and MM5 688 mesoscale models. Journal of Geophysical Research - Atmospheres, 117, 1-19. [29] Foley, A. M., Leahy, P. G., Marvuglia, A. and McKeogh, E. J. (2012). Current methods 690 and advances in forecasting of wind power generation. Renewable Energy, 37(1), 1-8.

691 [30] Hewitson, B. C. and Crane, R. G. (1996). Climate downscaling: techniques and 692 application. Climate Research, 7, 85-95.

693 [31] National Centers of Environmental Prediction/National Weather Service/NOAA/U.S. 694 Department of Commerce, 2000: NCEP FNL Operational Model Global Tropospheric 695 Analyses, continuing from July 1999. Research Data Archive at the National Center of 696 Atmospheric Research, Computational Information Systems Laboratory, Boulder, CO.

697 [32] National Center for Atmospheric Research (NCAR) Database. Available at:

698 https://www2.mmm.ucar.edu/wrf/users/download/get_sources_wps_geog.html. Accessed on 699 July 7, 2020. 
701 [34] Al-Yahyai, S., Charabi, Y. and Gastli, A. (2010). Review of the use of numerical 702 weather prediction (NWP) models for wind energy assessment. Renewable and Sustainable 703 Energy Reviews, 14, 3192-3198.

704 [35] Pielke Sr., R.A. (2002). Mesoscale Meteorological Modelling, second ed. Academic 705 Press, San Diego, CA.

706 [36] Hong, S-Y. \& Kanamitsu, M. (2014). Dynamical downscaling: Fundamental issues from 707 a NWP point of view and recommendations. Asia-Pacific Journal of Atmospheric Sciences, 708 50(1), 83-104.

709 [37] Carvalho, D., Rocha, A., Gómez-Gesteira, M. and Santos C. (2012). A sensitivity study 710 of the WRF model in wind simulation for an area of high wind energy. Environmental 711 Modelling \& Software, 33, 23-34.

712 [38] Mathew Sathyajith. Wind Energy: Fundamentals, Resource Analysis and Economics. 713 Berlin: Springer-Verlag; 2006.

714 [39] Manwell, J.F., McGowan J.G., and Rogers, A.L. Wind Energy Explained: Theory, 715 Design and Application. John Wiley \& Sons, Chichester, 2009.

716 [40] Ulrich, M., \& Bellon, G. (2019). Superenhancement of Precipitation at the Center of 717 Tropical Islands. Geophysical Research Letters, 46 (24), 14872-14880.

718 [41] NREL, National Renewable Energy Laboratory - Wind, 2018. Available at: 719 www.nrel.gov. Accessed on September 25, 2020.

720 [42] Mortensen, N.G., D.N. Heathfield, O. Rathmann and Morten Nielsen (2014). Wind Atlas 721 Analysis and Application Program: WAsP 12 Help Facility. Department of Wind Energy, 722 Technical University of Denmark, Roskilde, Denmark.

723 [43] Ricardo Guerrero-Lemus, Ignacio de la Nuez, Benjamín González-Díaz (2018). Rebuttal 724 letter to the article entitled: "Spatial planning to estimate the offshore wind energy potential 725 in coastal regions and islands. Practical case: The Canary Islands". Energy, 153, 12-16.

726 [44] Julieta Schallenberg-Rodríguez, Nuria García Montesdeoca, (2018). Spatial planning to 727 estimate the offshore wind energy potential in coastal regions and islands. Practical case: The 728 Canary Islands. Energy, 143, 91-103. 
729 [45] Julieta Schallenberg-Rodriguez (2013). A methodological review to estimate techno-

730 economical wind energy production. Renewable and Sustainable Energy Reviews, 21, 272-

731287.

732 [46] NASA Earth Observatory, 2021. Occurrence of El-Nino, La-Nina and ENSO. Available 733 at: http://www.earthobservatory.nasa.gov. Accessed on January 19, 2021.

734 [47] Larsén, X.G., Badger, J., Hahmann, A.N. and Mortensen, N.G. (2013). The selective 735 dynamical downscaling method for extreme- wind atlases. Wind Energy, 16, 1167-1182.

736 [48] Awan, N.K., H. Truhetz, and A. Gobiet, (2011). Parameterization-Induced Error 737 Characteristics of MM5 and WRF Operated in Climate Mode over the Alpine Region: An 738 Ensemble-Based Analysis. Journal of Climate, 24, 3107-3123.

739 